\title{
A Review on Synchronous Microalgal Lipid Enhancement and Wastewater Treatment
}

\author{
Visva Bharati Barua $\mathbb{1}$ and Mariya Munir*
}

Department of Civil and Environmental Engineering, University of North Carolina at Charlotte (UNCC), Charlotte, NC 28223, USA; vbarua@uncc.edu

* Correspondence: mmnunir@uncc.edu

check for updates

Citation: Barua, V.B.; Munir, M. A Review on Synchronous Microalgal Lipid Enhancement and Wastewater Treatment. Energies 2021, 14, 7687. https://doi.org/10.3390/en14227687

Academic Editors: Srikanth Vuppala and Javier Miguel Ochando-Pulido

Received: 6 October 2021

Accepted: 10 November 2021

Published: 17 November 2021

Publisher's Note: MDPI stays neutral with regard to jurisdictional claims in published maps and institutional affiliations.

Copyright: (c) 2021 by the authors. Licensee MDPI, Basel, Switzerland. This article is an open access article distributed under the terms and conditions of the Creative Commons Attribution (CC BY) license (https:// creativecommons.org/licenses/by/ $4.0 /)$.
Abstract: Microalgae are unicellular photosynthetic eukaryotes that can treat wastewater and provide us with biofuel. Microalgae cultivation utilizing wastewater is a promising approach for synchronous wastewater treatment and biofuel production. However, previous studies suggest that high microalgae biomass production reduces lipid production and vice versa. For cost-effective biofuel production from microalgae, synchronous lipid and biomass enhancement utilizing wastewater is necessary. Therefore, this study brings forth a comprehensive review of synchronous microalgal lipid and biomass enhancement strategies for biofuel production and wastewater treatment. The review emphasizes the appropriate synergy of the microalgae species, culture media, and synchronous lipid and biomass enhancement conditions as a sustainable, efficient solution.

Keywords: microalgae; lipid enhancement; biofuel; wastewater treatment

\section{Introduction}

Day by day, humankind creates many aspects of environmental pollution, mostly due to urbanization and industrialization. Fossil fuel depletion and the release of untreated wastewater are among the two most severe problems in recent times contributing to air and water pollution. Fossil fuel depletion increases the level of greenhouse gases in the environment. At the same time, untreated wastewater contains heavy metals, excess nutrients, and pathogens. Thus, both fossil fuel depletion and the release of untreated wastewater threatens human and ecological well-being. The rapidly growing pollution level has led to a call for desperate sustainable alternatives to be considered. Otherwise, an unpredictable climate and environmental changes may be activated, causing brutal health and ecological disruptions and, consequently, triggering the requirement of clean, sustainable energy resources and wastewater treatment at the same time.

Biological treatment seems to be a clean, sustainable alternative for environmental pollution mitigation. Microalgae are attributed with the distinct ability to offer ecological services and react to the sustainability challenges concurrently. In recent times, microalgae have gained attention worldwide for their significant potential in biofuel production and wastewater treatment besides mitigating atmospheric $\mathrm{CO}_{2}$. Microalgae can grow in nutrient-rich wastewater and reduce pollutants in the water bodies [1,2]. Microalgal bioremediation (phycoremediation) of wastewater also provides biofuels or high-value biomass yield for biofuel production simultaneously [3]. Pittman et al. [4] concluded that microalgae cultivation for biofuel devoid of wastewater is expensive with no positive energy return. Lundquist et al. [5] studied various microalgae-based wastewater treatments combined with biofuel production. They observed that the studies that utilized wastewater for microalgae cultivation could produce cost-effective biofuel, especially on a large scale.

Many previous studies have been reported on the phycoremediation of wastewater [6] and microalgae-based fuel production [7,8] (Table 1). Additionally, various studies have wastewater treatment combined with microalgae biofuel production. Min et al. [9] studied algal biomass production for biofuel while treating swine manure-based wastewater. They 
observed that the nutrient removal rate from the wastewater significantly correlated to the algal biomass productivity. The $\mathrm{NH}_{3}-\mathrm{N}, \mathrm{TN}, \mathrm{PO}_{4}-\mathrm{P}$, and $\mathrm{COD}$ reduction rates were observed to be $2.65,3.19,0.067$, and $7.21 \mathrm{~g} / \mathrm{m}^{2} \times$ day, respectively, and the algal biomass productivity ranged from $8.08-14.59$ and $19.15-23.19 \mathrm{~g} / \mathrm{m}^{2} \times$ day. However, a very low lipid content of $1.77-3.55 \%$ was observed for the harvested algal biomass. Mar et al. [10] studied the growth of Desmodesmus sp. S1 in oil refinery wastewater. Efficient wastewater treatment was achieved with $82 \%$ COD removal, 53\% total phosphorous removal, metal ions $\left(\mathrm{Fe}^{3+}, \mathrm{Al}^{3+}, \mathrm{Mn}^{2+}, \mathrm{Zn}^{2+}\right)$ removal, and pungent smell removal, whereas in Desmodesmus sp. S1, biomass and lipid contents were $2.98 \mathrm{~g} / \mathrm{L}$ and $21.95 \%$, respectively. Daneshvar et al. [11] reported the biomass productivity of $187 \mathrm{mg} / \mathrm{L} / \mathrm{d}$ and lipid content of $9.07 \%$ for Chlorella vulgaris in pulp and aquaculture wastewater. They witnessed efficient wastewater treatment showcasing $75.5 \%$ COD removal, $76.5 \%$ total nitrogen removal, and $92.7 \%$ total phosphorous removal. Thus, from most previous studies, it was observed that microalgae are efficient for wastewater treatment, but biomass production and lipid content are inversely related. This inverse relation of microalgae biomass production in wastewater and lipid content might be a bottleneck. High biomass production and high lipid content using wastewater as a culture media is a cost-effective, sustainable option. It is also feasible to stock up lipids in microalgae to a considerable amount by changing physio-chemical factors.

Table 1. Previous studies on microalgae cultivated in wastewater.

\begin{tabular}{|c|c|c|c|}
\hline Microalgae & Wastewater & Results & Reference \\
\hline Chlorella sp. UMN271 & Swine manure-based & $\begin{array}{c}\text { Biomass productivity ranged from } \\
8.08-14.59 \mathrm{~g} / \mathrm{m}^{2} \times \text { day and lipid content of } \\
1.77-3.55 \%\end{array}$ & [9] \\
\hline Desmodesmus sp. S1 & Oil refinery & $\begin{array}{l}\text { Biomass and lipid content were found to be } \\
2.98 \mathrm{~g} / \mathrm{L} \text { and } 21.95 \% \text {, respectively }\end{array}$ & [10] \\
\hline Chlorella vulgaris & Pulp and aquaculture & $\begin{array}{c}\text { Biomass productivity of } 187 \mathrm{mg} / \mathrm{L} / \mathrm{d} \text { and } \\
\text { lipid content of } 9.07 \%\end{array}$ & [11] \\
\hline Mix consortium & Carpet mill treated & $\begin{array}{l}\text { Biomass productivity of } 41 \mathrm{mg} / \mathrm{L} / \mathrm{d} \text { and } \\
\text { lipid content of } 12.2 \%\end{array}$ & [12] \\
\hline Chlorella pyrenoidosa & Soybean processing & Biomass productivity of $0.64 \mathrm{~g} / \mathrm{L} / \mathrm{d}$ & [13] \\
\hline Chlorella vulgaris & Tertiary-treated domestic & $\begin{array}{l}\text { Biomass productivity of } 197 \mathrm{gL}^{-1} \text { and lipid } \\
\text { productivity of } 0.164 \mathrm{gL}^{-1}\end{array}$ & [14] \\
\hline Scenedesmus bijuga & $\begin{array}{l}6 \% \text { effluent from poultry litter } \\
\text { anaerobic digestion }\end{array}$ & Biomass productivity of $31-76 \mathrm{mg} / \mathrm{L} / \mathrm{d}$ & [15] \\
\hline $\begin{array}{l}\text { Chlamydomonas sp. } \\
\text { TAI-2 }\end{array}$ & Untreated industrial & Biomass yield of $1.5 \mathrm{~g} / \mathrm{L}$ & [16] \\
\hline Desmodesmus sp. & Municipal & $\begin{array}{c}\text { Biomass productivity of } 500 \mathrm{mg} / \mathrm{L} / \mathrm{d} \text { and } \\
\text { lipid content of } 3.3 \%\end{array}$ & [17] \\
\hline C. sorokiniana & $\begin{array}{l}\text { Domestic wastewater with urea } \\
\text { supplementation }\end{array}$ & $\begin{array}{c}\text { Biomass productivity of } 200 \mathrm{mg} / \mathrm{L} / \mathrm{d} \text { and } \\
\text { lipid content of } 61.52 \%\end{array}$ & [18] \\
\hline $\begin{array}{l}\text { Scenedesmus obliquus } \\
\text { Chlorella sorokiniana } \\
\text { Ankistrodesmus falcatus }\end{array}$ & Aquaculture & $\begin{array}{l}\text { A. falcatus showed the highest biomass } \\
\text { productivity }\left(160.79 \mathrm{mg} \mathrm{L}^{-1} \mathrm{~d}^{-1}\right) \text { and lipid } \\
\text { productivity }\left(57.72 \mathrm{mg} \mathrm{L}^{-1} \mathrm{~d}^{-1}\right)\end{array}$ & [19] \\
\hline $\begin{array}{l}\text { Desmodesmus spp. } \\
\text { S. obliquus }\end{array}$ & $\begin{array}{l}\text { Municipal wastewater with } \\
\text { different leachate }\end{array}$ & $33 \%$ increase in lipid content & [20] \\
\hline Chlorella sp. & Municipal wastewater & Lipid content of $34.83 \%$ & [21] \\
\hline Scenedesmus obliquus & Municipal wastewater & $0.33-0.38 \mathrm{~g} \mathrm{~L}^{-1}$ of total lipid & [22] \\
\hline
\end{tabular}

There are many review papers available that focus on using microalgae for wastewater treatment, biofuel production, or even integration of both processes. However, this review paper emphasizes the microalgae lipid enhancement strategies by not compromising the biomass productivity and utilizing wastewater as the growth media. Challenges such as high prices can be reduced by coupling wastewater treatment with high biomass and lipid productivity for biofuels. As the review was on synchronous microalgae lipid enhancement and wastewater treatment, the major keywords utilized for identifying literatures were 
microalgae, wastewater, lipid enhancement, and biofuel. The time frame for sorting the literature search was from 2002 to 2021.

\section{Functioning of Microalgae}

Microalgae are photosynthetic organisms functioning in presence of nutrients, light, and $\mathrm{CO}_{2}$ to grow (Figure 1). Besides nutrients, light, and $\mathrm{CO}_{2}$, many other environmental factors (temperature, $\mathrm{pH}$ ) determine their growth rate. As microalgae uptake nutrients for growth, many studies have utilized microalgae for nutrient removal from wastewater. This process of excess nutrient removal from water bodies by microalgae is known as phycoremediation. Microalgae have also found their usage in biofuel production as they are rich in lipids.
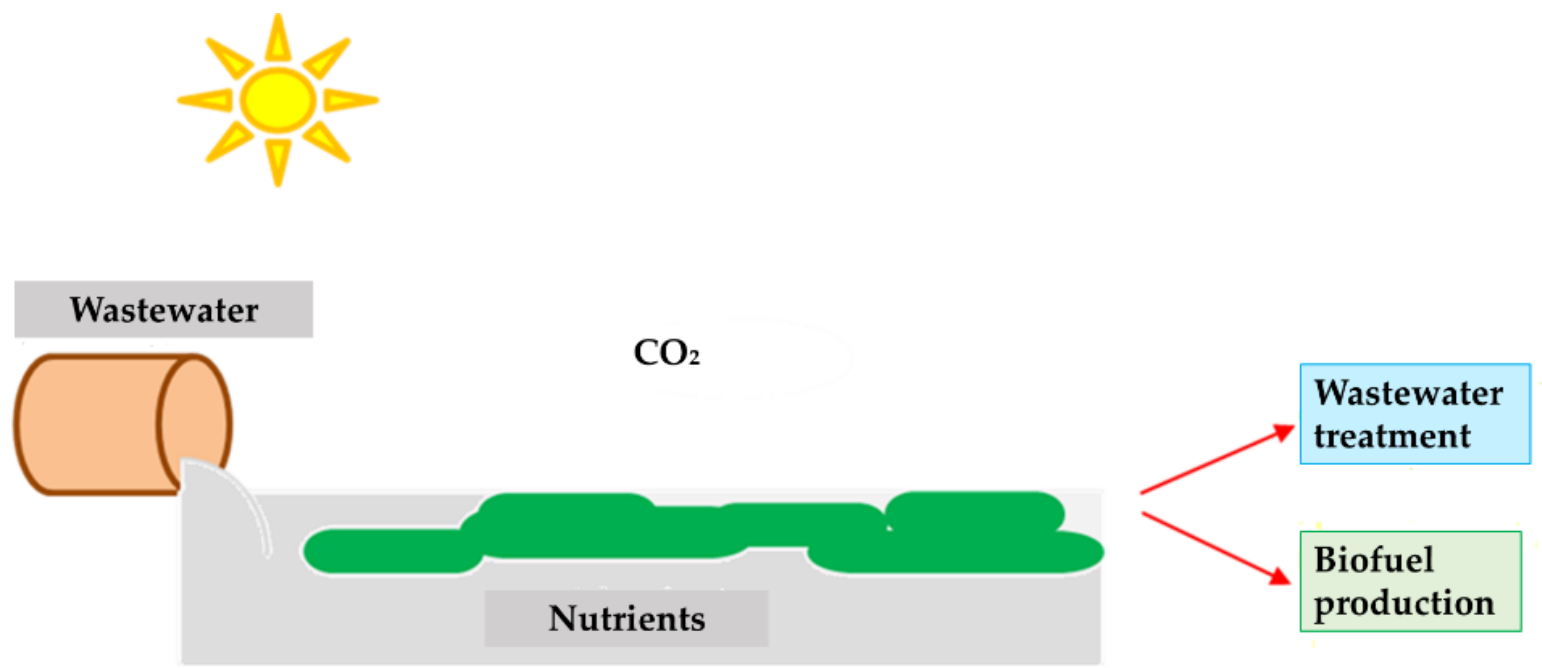

Figure 1. Pictorial representation of the functioning of microalgae for wastewater treatment and biofuel production.

\subsection{Wastewater Treatment}

Microalgae cultivation for wastewater treatment is an old practice. Microalgae are capable of producing oxygen $\left(\mathrm{O}_{2}\right)$ through photosynthesis during cultivation. The produced oxygen can be used to degrade organic contaminants and phycoremediate inorganic compounds available in the wastewater. Thus, photosynthetic oxygen eradicates the necessity to supply air through the conventional aeration process, decreasing the cost drastically. To reduce the probability of eutrophication, microalgal ponds were designed to treat the secondary effluent before release in aquatic bodies. Microalgae can also eliminate the nutrients $(\mathrm{N}, \mathrm{K})$ more proficiently in wastewater than conventional treatment routes.

\subsection{Biofuel Production}

Microalgae can convert atmospheric $\mathrm{CO}_{2}$ into carbohydrates and lipids [7]. Lipids produced by microalgae can be divided into polar lipids (glycerophospholipids), which have an important role in cell structure, and non-polar lipids (triacylglycerols, TAGs) mainly responsible for energy storage. Lipids are stocked up in microalgae in diverse ways based on the species, growth phase, and environmental conditions. When photosynthesis occurs in microalgae, non-polar lipids such as TAGs accumulate in the cells [23]. TAGs are modified into fatty acid methyl esters by trans-esterification for biofuel production [8].

Microalgal lipid production is around 15-300 times more than the oil-bearing crops (palm, corn, soybean, and sunflower) [24]. Microalgae are competent and preferable to produce biofuels as they do not require land and freshwater for cultivation. The best way to produce high amounts of these lipids is to sustain global energy demands through high microalgal biomass productivity. Previous studies have reported that accomplishing both factors synchronously is very difficult [25]. Although there are many challenges for microalgal biofuel production, researchers believe that microalgal biofuel is still a 
promising alternative for fossil fuel. A new focus in microalgal biofuel research is to optimize an ideal condition to achieve a high growth rate of microalgae while producing high lipid content under a stressful environment. Therefore, various approaches to enhance the lipid production rate in microalgae have been investigated.

\section{Strategies for Lipid Enhancement}

This section may be divided by subheadings. It should provide a concise and precise description of the experimental results, their interpretation, as well as the experimental conclusions that can be drawn.

\subsection{Selection of Proper Microalgae Species or Strain}

In various kinds of literature, altering the culture condition has been mentioned as a strategy for lipid enhancement in microalgae. However, biofuel production's primary drawback cannot be conquered if the microalgae species/strain is not suitable for the purpose. Microalgae have been under the limelight for their lipid-producing capability [26]. Lipid content and growth rate in microalgae vary from species to species. Lipid production by microalgae for commercial purposes undergoes tough challenges as microalgae display two different traits, either low lipid accumulation with high biomass production or vice versa. The microalgae Botryococcus braunii has a lipid content of $25-75 \%$ but a low growth rate, Chlorella vulgaris has a lipid content of $28-58 \%$ and a very high growth rate, Dunaliella salina has a low lipid content of $6-25 \%$ and a moderate growth rate, and Nannochloropsis oculata has a lipid content of $23-30 \%$ and a high growth rate [27]. Although lipid production in microalgae is species-specific, sometimes it is also strain-specific. The same microalgal species of a different strain can vary in lipid composition as well. Yamaguchi et al. [28] studied two different B. braunii strains under the same culture conditions and media. They reported that the lipid composition is different for both the strains, although biomass and lipid yields are similar. Growth characteristics and lipid production can vary for the same species/strain based on the growth media composition and other physio-chemical factors (light, carbon dioxide, temperature, salinity) [29]. Ruangsomboon [30] chronologically changed growth conditions (nitrogen, phosphorus, iron, light, salinity, and cultivation time) for B. braunii (KMITL2) in chlorella medium. At $25^{\circ} \mathrm{C}, 222 \mathrm{mg} / \mathrm{L}$ phosphorus concentration and continuous illumination of $200 \mu \mathrm{E} \mathrm{m}^{-2} \mathrm{~s}^{-1}$, the maximum lipid yield of $0.48 \mathrm{mg} / \mathrm{L}$ and biomass yield of $0.8 \mathrm{~g} / \mathrm{L}$ was obtained. When phosphorus concentration was increased to $444 \mathrm{mg} / \mathrm{L}$, lipid yield $(0.45 \mathrm{~g} / \mathrm{L})$ and biomass concentration $(1.91 \pm 0.03 \mathrm{~g} / \mathrm{L})$ were also enhanced.

Hence, the first step for the microalgae cultivations is to determine or engineer the proper species/strain for the specific function and intention. As enhancing lipid productivity is hindered by swapping between lipid accumulation and cell growth, numerous endeavors are being made to decipher these bottlenecks, from choosing oleaginous species, strain development, and strain acclimation, to diverse cultivation media and conditions [31].

\subsection{Selection of Proper Growth Media}

The growth of microalgae necessitates the need for light, carbon dioxide, water, and nutrients, nitrogen and phosphorus being the chief nutrients required for their growth. For phototrophic culture, BG-11 and Chu 13 are the most used growth media with $\mathrm{CO}_{2}$ supplementation [32-35], as BG-11 and Chu 13 contain all the significant nutrients necessary for the growth of microalgae, whereas for mixotrophic culture, synthetic media with organic carbon sources are mostly utilized [36]. Yeh and Chang [37] investigated the growth and lipid productivity of Chlorella vulgaris ESP-31 in different media (Basal medium and Modified Bristol's medium) and cultivation conditions. At phototrophic, photoheterotrophic, and mixotrophic conditions, C. vulgaris ESP-31 obtained a biomass concentration of $2-5 \mathrm{~g} / \mathrm{L}$ in nitrogen-rich media. C. vulgaris ESP-31 growth on nitrogen limiting media exhibited enhanced lipid build-up (20-53\%) with a slower growth rate. 
When all the culture media were utilized at mixotrophic conditions, enhanced lipid content (40-53\%) and enhanced lipid productivity (67-144 mg/L/d) were achieved. Hence, growth media and cultivation conditions influence microalgal growth and lipid accumulation to a great extent.

A huge quantity of water is essential for the microalgae cultivation process. Yang et al. [38] assessed that to generate $1 \mathrm{~kg}$ of microalgal biofuel, $3726 \mathrm{~kg}$ of water is necessary, and this prerequisite can be reduced by $90 \%$ via wastewater utilization. Saranya and Shanthakumar [39] investigated the performance of Chlorella vulgaris (NRMCF0128) and Pseudochlorella pringsheimii (VIT_SDSS) using combined sewage and tannery effluent at varying dilution. At a higher dilution (up to 30\%) of tannery effluent both the species exhibited a drop in pollutant concentration: $>65 \%$ for $\mathrm{NH}_{3}-\mathrm{N}, 100 \%$ for $\mathrm{PO}_{4}-\mathrm{P},>63 \%$ for $\mathrm{COD}$, and $>80 \%$ for total chromium. They observed the maximum biomass yield of $3.51 \mathrm{~g} / \mathrm{L}$ for Chlorella vulgaris at $30 \%$ tannery effluent, whereas it was for Pseudochlorella pringsheimii $2.84 \mathrm{~g} / \mathrm{L}$ at for $20 \%$ tannery effluent. Additionally, P. pringsheimii exhibited an enhanced lipid accumulation of $25.4 \%$, which was greater than that of Chlorella vulgaris (9.3\%). They also reported that at $20 \%$ dilution, the lipid accumulation of $P$. pringsheimii was 5 times and 1.5 times more than undiluted sewage- and BG11-grown microalgae. Hence, it is evident that Pseudochlorella pringsheimii when grown in 20\% tannery effluent assists in biomass growth, lipid enhancement, and treatment of wastewater.

Utilization of post-fermentation leachate from biogas plants, including the wastewater after the initial stage of anaerobic digestion, is a favorable route for microalgae biomass production and wastewater treatment. The post-fermentation wastewater comprises a high content of nitrogen and phosphorus, significant amounts of dissolved carbon dioxide, and low organics. A. prothecoides when cultivated in post-fermentation wastewater reported $79.45 \%$ nitrogen removal, $78.4 \%$ phosphorus removal, and the maximum lipid content of $44.65 \%$ [40].

Wastewater can serve as an excellent medium for microalgae cultivation as it contains the nutrients necessary for its growth. The utilization of wastewater as a growth medium for microalgae is an economical step as wastewater is easily available in plenty and there is no need to add nutrients as a supplement. The addition of nutrients for microalgae growth can be expensive if required in huge quantities. Wastewater utilization reduces the surplus cost of nutrient addition, especially in large-scale cultivation [41]. Furthermore, using wastewater as a growth medium for microalgae induces wastewater treatment. Therefore, wastewater utilization for microalgae growth is an economical and sustainable alternative.

\subsection{Selection of Proper Stress Condition}

Microalgae tend to stock up a substantial amount of lipids under stress. However, the stressful culture condition where lipid (TAGs) synthesis takes place simultaneously stimulates protein biodegradation, compromising on cell growth and biomass productivity. There are quite a few physio-chemical stress factors that perk up the stimulation of lipid accumulation such as light, temperature, $\mathrm{CO}_{2}$, nutrients, and salinity (Table 2). Diverse microalgae species/strains respond differently to different stress conditions, thereby producing different quantities and composition of lipids in different microalgae species/strains. This alteration in the microalgae lipid metabolism can enhance the lipid basal level. 
Table 2. Different microalgae responses to various stress conditions.

\begin{tabular}{|c|c|c|c|c|}
\hline Microalgae & Media & Stress Condition & Result & Reference \\
\hline Desmodesmus spp. & $\begin{array}{l}\text { Municipal wastewater } \\
\text { with leachate }\end{array}$ & $\begin{array}{l}\text { Intensity of } 53 \mu \mathrm{mol} / \mathrm{m}^{2} / \mathrm{s} \text { and } \\
\text { light cycles of } 12: 12 . \\
\text { High ammonia concentration } \\
(\geq 167 \mathrm{mg} / \mathrm{L})\end{array}$ & $\begin{array}{l}\text { Biomass productivity of } 1.95 \mathrm{~g} / \mathrm{L} \\
\text { and lipid content of } 20 \%\end{array}$ & [20] \\
\hline P.kessleri NKG021201 & Municipal wastewater & $\begin{array}{l}\text { Illumination at } 40 \mathrm{mmol} / \mathrm{m}^{2} / \mathrm{s} \\
\text { at } 25^{\circ} \mathrm{C}\end{array}$ & $\begin{array}{l}\text { Biomass productivity of } \\
125 \pm 8 \mathrm{mg} / \mathrm{L} / \mathrm{d} \text { and lipid } \\
\text { content of } 38 \pm 1 \%\end{array}$ & [29] \\
\hline $\begin{array}{l}\text { Nannochloropsis oculate } \\
\text { Chlorella vulgaris }\end{array}$ & $\begin{array}{l}\text { Bold's Basal Medium for } \\
\text { C. vulgari } \\
\text { f2 for N. oculata }\end{array}$ & $\begin{array}{c}20^{\circ} \mathrm{C} \text { for } \mathrm{N} \text {. oculata and } 30^{\circ} \mathrm{C} \text { for } \\
\text { C. vulgaris } \\
\text { Nitrogen deficiency } \\
\mathrm{CO}_{2} \text { contained in air (about } \\
300 \mathrm{ppm} \text { ) }\end{array}$ & $\begin{array}{l}\text { Lipid yield enhanced to } 15.31 \% \\
\text { for N. oculata and } 16.41 \% \text { for } \\
\text { C. vulgaris }\end{array}$ & [42] \\
\hline Scenedesmus sp. & BG11 & $\begin{array}{l}\text { Light intensity of } 55-60 \mu \mathrm{mol} \\
\text { photon } \mathrm{m}^{-2} \mathrm{~s}^{-1}, \text { light } / \text { dark } \\
\text { ratio of } 14: 10 \text { at } 25^{\circ} \mathrm{C} \\
\text { Phosphate } \\
\text { deficiency }\end{array}$ & Lipid accumulation of 53\% & [43] \\
\hline $\begin{array}{l}\text { C. mexicana GU73240 } \\
\text { S. obliquus HM103382 }\end{array}$ & Bold basal medium & $\begin{array}{c}\text { Illumination at } 40 \mu \mathrm{mol} \\
\text { (photon) } / \mathrm{m}^{2} \mathrm{~s} \text { at } \\
27^{\circ} \mathrm{C} \text { for } 20 \text { days } \\
\text { Increased } \mathrm{NaCl} \text { dose }\end{array}$ & $\begin{array}{l}\text { Highest dry weight ( } 0.8 \text { and } \\
0.65 \mathrm{~g} / \mathrm{L} \text { ) and lipid content ( } 37 \\
\text { and } 34 \% \text { ) of C. mexicana and } \\
\text { S. obliquus repectively }\end{array}$ & [44] \\
\hline $\begin{array}{l}\text { N. oceanica } \\
\text { DUT01 }\end{array}$ & $\begin{array}{l}\mathrm{f} / 2 \text { seawater } \\
\text { BG } 11\end{array}$ & $\begin{array}{c}14 / 10 \mathrm{~h} \text { light } / \text { dark cycle under } \\
\text { an intensity of } 60 \mu \mathrm{mol} \mathrm{m}^{-2} \mathrm{~s}^{-1} \\
\text { at } 25^{\circ} \mathrm{C} \\
2 \% \mathrm{CO}_{2} \\
\text { Nitrogen rich }\end{array}$ & $\begin{array}{l}\text { Lipid productivity of } \\
\qquad 31 \mathrm{mg} \mathrm{L}^{-1} \mathrm{~d}^{-1}\end{array}$ & [45] \\
\hline Ankistrodesmus falcatus & $\begin{array}{l}\text { Blue-Green (BG11) } \\
\text { medium }\end{array}$ & $\begin{array}{c}\text { Photon flux of } \\
120 \mu \mathrm{mol} \mathrm{m}^{-2} \mathrm{~s}^{-1} \text {, under a } \\
16 \mathrm{~h}: 8 \mathrm{~h} \text { light dark cycle at } 25^{\circ} \mathrm{C} \\
\text { Iron sufficient } \\
\text { and deficient }\end{array}$ & $\begin{array}{l}\text { At } 3 \mathrm{mg} \mathrm{L}^{-1} \text { the lipid content } \\
\text { and productivity decreased } \\
\text { whereas lipid content and } \\
\text { productivity enhanced at } \\
6 \mathrm{mg} \mathrm{L}^{-1} \text { iron concentration } \\
\text { Scenedesmus obliquus yielded the }\end{array}$ & [46] \\
\hline $\begin{array}{l}\text { Chlorella vulgaris } \\
\text { Chlorella kessleri } \\
\text { Scenedesmus obliquus }\end{array}$ & $\begin{array}{l}\text { Secondary treated urban } \\
\text { wastewater }\end{array}$ & $\begin{array}{c}\text { Illumination of } \\
143 \mu \mathrm{mol} \cdot \mathrm{m}^{-2} \cdot \mathrm{s}^{-1} \text { and } 14 / 10 \\
\text { light } / \text { dark cycle at } 20 \pm 1{ }^{\circ} \mathrm{C} \\
4 \% \mathrm{CO}_{2}\end{array}$ & $\begin{array}{l}\text { highest biomass concentration } \\
(1.4 \mathrm{~g} / \mathrm{L}) \text { and lipid content } \\
(36.75 \%) \\
\text { C. vulgaris reached the highest } \\
\text { biomass productivity } \\
(0.107 \mathrm{~g} / \mathrm{L} \cdot \mathrm{d}) \text { followed by } \\
\text { S.obliquus }(4.4 \mathrm{mg} \text { Total } \mathrm{N} / \mathrm{L} \cdot \mathrm{d})\end{array}$ & [47] \\
\hline $\begin{array}{l}\text { Mixed consortium mainly } \\
\text { consisted of Chlorella sp. }\end{array}$ & $\begin{array}{l}\text { Mixed waste streams } \\
\text { (liquid digestate obtained } \\
\text { after the filtration of the } \\
\text { compost, liquid coming } \\
\text { from the septic system } \\
\text { sludge treatment plant } \\
\text { and an effluent coming } \\
\text { from the wastewater } \\
\text { treatment plant) }\end{array}$ & $\begin{array}{l}\text { Photoperiod of } 12: 12 \mathrm{~h} \text { at } 20^{\circ} \mathrm{C} \\
\mathrm{CO}_{2} \text { supplemented at a rate of } \\
0.2 \text { volume of air per volume of } \\
\text { medium per minute (vvm) }\end{array}$ & $\begin{array}{c}\text { Biomass productivity } \\
\left(105.2 \mathrm{mg} \cdot \mathrm{L}^{-1} \cdot \mathrm{d}^{-1}\right) \text { was } \\
\text { negatively affected by } \mathrm{CO}_{2} \\
\text { addition and positively affected } \\
\text { by light intensity. } \\
\text { Higher lipid contents }(17.2 \%) \\
\text { were found at low light intensity }\end{array}$ & [48] \\
\hline $\begin{array}{l}\text { C. protothecoides } \\
\text { UTEX-256 }\end{array}$ & $\begin{array}{l}\text { Pretreated dairy } \\
\text { wastewater }\end{array}$ & $\begin{array}{c}5 \% \mathrm{CO}_{2} \text { was supplied } \\
\text { light intensity was } 150 \mu \mathrm{mol} \\
\mathrm{m}^{-2} \mathrm{~s}^{-1} \text { for } 9 \text { days }\end{array}$ & $\begin{array}{l}40 \% \text { pretreated whey was most } \\
\text { productive for biomass and lipid } \\
\text { fractions, respectively, } 4.54 \text { and } \\
1.80 \mathrm{gL}^{-1} \text { with daily } \\
\text { productivities } 0.50 \text { and } \\
0.20 \mathrm{gL}^{-1} \mathrm{~d}^{-1}\end{array}$ & [49] \\
\hline Chlorella vulgaris & $\begin{array}{l}\text { Chicken waste compost } \\
\text { mixed with tap water }\end{array}$ & $\begin{array}{l}1 \text { day of nutrient starvation with } \\
6 \mathrm{~g} / \mathrm{L} \text { of salinity stress at dark }\end{array}$ & $\begin{array}{l}\text { Lipid content was recorded at } \\
40.28 \%\end{array}$ & [50] \\
\hline Chlorella vulgaris & BG11 medium & $\begin{array}{c}\text { Illumination at } 135 \mu \mathrm{mol} \text { photon } \\
\mathrm{m}^{-2} \mathrm{~s}^{-1} \text { at } 25^{\circ} \mathrm{C} \\
\text { low concentration of } \mathrm{Cr}(\mathrm{VI})\end{array}$ & $\begin{array}{l}\text { Biomass productivity of } \\
28.3-35.9 \mathrm{mg} \mathrm{L}^{-1} \mathrm{~d}^{-1}\end{array}$ & [51] \\
\hline
\end{tabular}

\subsubsection{Effect of Light}

Light is one of the most indispensable factors for the production of microalgal biomass. Light provides energy for the process of photosynthesis and microbial growth. The intensity of light and its wavelength can drastically modify microalgal growth and lipid accumulation (Table 3). Wahidin et al. [52] in Nannochloropsis sp (marine microalga) noticed an enhanced lipid accumulation of up to $31.3 \%$ after 8-day cultivation under $100 \mu \mathrm{mol} \mathrm{m}^{-2} \mathrm{~s}^{-1}$ 
light intensity and a photoperiod of $18 \mathrm{~h}$ light: $6 \mathrm{~h}$ dark cycle. They also observed a gradual decline in cell density and growth rate during the $24 \mathrm{~h}$ photoperiod cycle. Zhu et al. [8] reported that extreme light intensities affected the lipid content by photo-inhibition and photo-oxidation. Generally, microalgae encompass a light saturation limit of $600 \mathrm{ft}$. candles approximately. Exposure of microalgae to light intensity more than the light saturation limit causes oxidative stress [52]. Excessive photo-assimilation causes lipid stock up as a self-defense mechanism to prevent photo-oxidative damage, thus transforming the surplus light energy into chemical energy [53,54]. For Chlorella sp. L1, the high light intensity of $400 \mu \mathrm{mol}$ photon $\mathrm{m}^{-2} \mathrm{~s}^{-1}$ exhibited neutral lipid productivity of $51.4 \mathrm{mg} \mathrm{L}^{-1} \mathrm{~d}^{-1}$ by He et al. [55]. Ruangsomboon [30] reported that Botryococcus braunii KMITL 2 exposed to high light intensities of 200 and $538 \mu \mathrm{E}^{-2} \mathrm{~s}^{-1}$ stocked up more lipid than those grown at lower light intensity $\left(87.5 \mu \mathrm{E} \mathrm{m}^{-2} \mathrm{~s}^{-1}\right)$. On the other hand, Phaeodactylum tricornutum at a low light intensity of $60 \mu \mathrm{mol}$ photons $\mathrm{m}^{-2} \mathrm{~s}^{-1}$ exhibited the highest TAG yield of $112 \mathrm{mg} \mathrm{mol}_{\mathrm{ph}}{ }^{-1}$ [31] This indicates that the light intensity, which may be low for few microalgae species, can be high for some other microalgae species. The microalgae Nannochloropsis sp. produces the enhanced lipid content ( $47 \%$ of dry weight) at a light intensity of $700 \mu \mathrm{mol}$ photons $/ \mathrm{m}^{2} / \mathrm{s}$ [56]. Liu et al. [57] reported that lipid accumulation in Scenedesmus sp. enhanced 11-fold at a light intensity of $400 \mu \mathrm{mol}$ photons $/ \mathrm{m}^{2} / \mathrm{s}$, whereas at a light intensity of $600 \mu \mathrm{mol}$ photons $/ \mathrm{m}^{2} / \mathrm{s}$, microalgae species C. sorokiniana, C. viscosa, C. emersonii, C. vulgaris, P. beijerinckii, and P. kessleri CCALA255, NIES-2152, and NIES-2159 produced enhanced lipids [58]. Liao et al. [59] confirmed that Chlorella vulgaris at a high light intensity of $560 \mu \mathrm{E} \mathrm{m}^{-2} \mathrm{~s}^{-1}$ exhibited a $92.89 \%$ enhanced lipid yield, greater than the lower intensity of $160 \mu \mathrm{E} \mathrm{m}^{-2} \mathrm{~s}^{-1}$. In some microalgae species such as Scenedesmus obliquus, lipid content remained the same when light intensity changed from 200 to $1500 \mu \mathrm{mol}$ photons $/ \mathrm{m}^{2} / \mathrm{s}[60]$.

Table 3. Different microalgae responses to light conditions.

\begin{tabular}{|c|c|c|c|}
\hline Microalgae & Stress Condition & Result & Reference \\
\hline Botryococcus braunii KMITL 2 & Light intensities of 200 and $538 \mu \mathrm{E}^{-2} \mathrm{~s}^{-1}$ & $\begin{array}{l}\text { More lipid accumulation than lower } \\
\text { light intensity of } 87.5 \mu \mathrm{E} \mathrm{m}^{-2} \mathrm{~s}^{-1}\end{array}$ & [30] \\
\hline Phaeodactylum tricornutum & $\begin{array}{l}\text { Light intensity of } \\
60 \mu \mathrm{mol} \text { photons } \mathrm{m}^{-2} \mathrm{~s}^{-1}\end{array}$ & TAG yield of $112 \mathrm{mg} \mathrm{mol}_{\mathrm{ph}}{ }^{-1}$ & [31] \\
\hline Nannochloropsis sp. & $\begin{array}{l}100 \mu \mathrm{mol} \mathrm{m} \mathrm{m}^{-2} \mathrm{~s}^{-1} \text { light intensity } \\
\text { photoperiod of } 18 \mathrm{~h} \text { light: } 6 \mathrm{~h} \text { dark cycle }\end{array}$ & $\begin{array}{l}\text { Enhanced lipid accumulation of up } \\
\text { to } 31.3 \%\end{array}$ & [52] \\
\hline Chlorella sp. L1 & $400 \mu \mathrm{mol}$ photon $\mathrm{m}^{-2} \mathrm{~s}^{-1}$ light intensity & $51.4 \mathrm{mg} \mathrm{L}^{-1} \mathrm{~d}^{-1}$ lipid productivity & [55] \\
\hline Nannochloropsis sp. & $\begin{array}{l}\text { Light intensity of } \\
700 \mu \mathrm{mol} \text { photons } / \mathrm{m}^{2} / \mathrm{s}\end{array}$ & $\begin{array}{c}\text { Enhanced lipid content (47\% of } \\
\text { dry weight) }\end{array}$ & [56] \\
\hline Scenedesmus sp. & $\begin{array}{c}143 \mu \mathrm{mol} \cdot \mathrm{m}^{-2} \cdot \mathrm{s}^{-1} \text { and } 14 / 10 \text { light } / \text { dark } \\
\text { cycle at } 20 \pm 1{ }^{\circ} \mathrm{C}\end{array}$ & Lipid accumulation enhanced & [57] \\
\hline Chlorella vulgaris & Light intensity of $560 \mu \mathrm{E} \mathrm{m}^{-2} \mathrm{~s}^{-1}$ & $92.89 \%$ enhanced lipid yield & [59] \\
\hline Scenedesmus obliquus & $\begin{array}{l}\text { 200-1500 } \mu \text { mol photons } / \mathrm{m}^{2} / \mathrm{s} \\
\text { light intensity }\end{array}$ & Lipid content remained the same & {$[60]$} \\
\hline
\end{tabular}

Besides light intensity, previous studies are reporting the influence of varying light wavelengths on microalgae growth and metabolism. The microalgae chlorophyll has an absorption band $(630-675 \mathrm{~nm})$ in red and blue $(450-475 \mathrm{~nm})$ spectral region [61]. The phenomenon of microalgae using light energy obtainable within the wavelength of 400-700 nm is known as photosynthetically active radiation (PAR). Das et al. [62] exposed Nannochloropsis sp. to different light wavelengths (red, green, blue, and white). They reported the highest fatty acid methyl esters (FAME) content under green LED $(550 \mathrm{~nm})$. Nevertheless, the maximum volumetric FAME yield was achieved under blue LED $(470 \mathrm{~nm})$ owing to maximum biomass productivity at this wavelength. Hultberg et al. [63] observed that Chlorella vulgaris exposed to light at green wavelengths illustrated enhanced polyunsaturated fatty acids (C16:3 and C18:3). According to Rai et al. [64], the best growth and the highest lipid accumulation for Chlorella sp. were obtained in red light, whereas green 
light demonstrated weak biomass growth and less lipid production. Wong et al. [65] demonstrated that Chlorella vulgaris grown in wastewater using blue light achieved the highest lipid content (34.06\%) after 10 days of 18:6 light/dark periods, with an initial cell number of 106 cells $/ \mathrm{mL}$. Severes et al. [66] reported that a combination of red $(600-700 \mathrm{~nm})$ and blue (400-500 nm) light wavelength for a culture of Chlorella sp. increases biomass production. They also observed that red light wavelength doubled the dry weight of lipids in Chlorella cells during the growth period.

Microalgae seem to produce more polar lipids during low light intensity due to enhanced chloroplast membrane synthesis. A gradual increase in light intensity tends to stock up more neutral lipids without hampering the biomass yield. Both low and extremely high light intensity leads to adverse growth and responses in cells. Therefore, determining the ideal intensity of light helps acquire optimal microalgal growth and enhanced lipid production $[53,67]$. However, the intensity of light required to attain the maximum growth, and lipid content varies from species to species. Hence, complementing irradiation of the light bands for the constitutive pigments (chlorophyll, phycobilins, and carotenoids) can increase the photosynthetic rate and lipid productivity with reduced energy consumption.

\subsubsection{Effect of Temperature}

The temperature has a vital effect on microalgae growth and lipid production (Table 4). Temperature can operate as a stress factor that can bump up the reactive oxygen species level and stimulate neutral lipids, i.e., TAGs [68]. Biochemical pathways for lipid synthesis and stock up are regulated by enzymes that are very sensitive to thermal variations [69]. Converti et al. [42] investigated thermal variation $\left(20\right.$ to $\left.25^{\circ} \mathrm{C}\right)$ with respect to lipid content for N. oculata and C. vulgaris. They observed that a rise in temperature leads to a drop in lipid content in C. vulgaris and vice versa, whereas for $N$. oculata a rise in temperature led to enhanced lipid production by 2 -fold (7.90-14.92\%). Subhash et al. [70] observed a 5-fold rise in neutral lipid at a high temperature of $30^{\circ} \mathrm{C}$ in a mixed microalgae culture for wastewater treatment. Bohnenberger and Crossetti [71] reported that for Monoraphidium consortiums and Desmodesmus quadricauda, a lower temperature of $13^{\circ} \mathrm{C}$ aids in lipid accumulation. Freire et al. [72] observed the highest growth and lipid productivity for Nannochloropsis limnetica at $22{ }^{\circ} \mathrm{C}$, whereas for Heterochlorella luteoviridis, Menegol et al. [73] observed $40.7 \%$ of PUFAs at a temperature of $22{ }^{\circ} \mathrm{C}$, whereas the percentage of saturated fatty acids was increased (52.9\%) at $27^{\circ} \mathrm{C}$. Xin et al. [43] reported enhanced lipid build-up at lower temperatures of $10-20^{\circ} \mathrm{C}$ than at $25^{\circ} \mathrm{C}$ for Scenedesmus sp. LX1. Wei et al. [74] reported that the optimal temperature for lipid stock up for Tetraselmis subcordiformis was $20^{\circ} \mathrm{C}$ and for N. oculata $30^{\circ} \mathrm{C}$. Xin et al. [68] reported that almost all of the fatty acids and longchain species (C16-C18) were saturated at a high temperature of $30^{\circ} \mathrm{C}$ for Scenedesmus sp. LX1. Analogous results were also reported by Renaud et al. [75] for the microalgae Rhodomonas sp., Cryptomonas sp., and Prymnesiophyte NT19, respectively.

Table 4. Different microalgae responses to the effect of temperature.

\begin{tabular}{ccccc}
\hline Microalgae & Stress Condition & Result & Reference \\
\hline $\begin{array}{c}\text { N. oculata } \\
\text { C. vulgaris }\end{array}$ & $20-25^{\circ} \mathrm{C}$ & $\begin{array}{c}\text { Increased temperature decreases lipid content in C. } \\
\text { vulgaris and increases lipid production for N.oculata }\end{array}$ & [42] \\
Mixed microalgae culture & $30{ }^{\circ} \mathrm{C}$ & 5-fold rise in neutral lipid & [70] \\
$\begin{array}{c}\text { Monoraphidium consortiums } \\
\text { Desmodesmus quadricauda }\end{array}$ & $13{ }^{\circ} \mathrm{C}$ & Aids in lipid accumulation & [71] \\
Nannochloropsis limnetica & $22{ }^{\circ} \mathrm{C}$ & highest growth and lipid productivity was observed & [72] \\
Heterochlorella luteoviridis & $22-27^{\circ} \mathrm{C}$ & $40.7 \%$ of PUFAs at a temperature of 22 ${ }^{\circ} \mathrm{C}$, whereas 52.9\% & [73] \\
Scenedesmus sp. LX1. & $10-25^{\circ} \mathrm{C}$ & saturated fatty acids increased at 27 ${ }^{\circ} \mathrm{C}$ & Enhanced lipid build-up at low temperature \\
Scenedesmus sp. LX1 & $30{ }^{\circ} \mathrm{C}$ & Most of the fatty acids saturated & [43] \\
\hline
\end{tabular}


Although the optimal temperature for microalgae growth and lipid production differs from species to species, still, in many microalgae species, high temperature favors saturated fatty acid formation, which is maneuvered by the cell membrane fluidization. The fluidity of phospholipid bilayers is enhanced when the number of double bonds increases [76]. Furthermore, the fatty acid composition of microalgae is also influenced by temperature.

\subsubsection{Effect of Carbon Dioxide $\left(\mathrm{CO}_{2}\right)$}

Atmospheric $\mathrm{CO}_{2}$ is another essential component for microalgal growth. $\mathrm{CO}_{2}$ is a source of carbon for microalgae cell development. Microalgae capture the atmospheric $\mathrm{CO}_{2}$ in the presence of sunlight to produce biomass and chemical compounds of interest (Table 5). Zhu et al. [8] stated an optimum range of $\mathrm{CO}_{2}$ necessary for the growth, lipid production, and accumulation within the microalgae. A high concentration of $\mathrm{CO}_{2}$ helped Nannochloropsis species, but for some microalgae species, a high concentration of $\mathrm{CO}_{2}$ is toxic [77]. Chiu et al. [78] reported lipid productivity of 142 and $82 \mathrm{mg} \mathrm{L}^{-1} \mathrm{~d}^{-1}$ for N. oculata when aerated with $2 \%$ and $15 \% \mathrm{CO}_{2}$, respectively. Jiang et al. [14] for Nannochloropsis sp. observed an increase in biomass productivity $\left(0.39-1.43 \mathrm{gL}^{-1}\right)$ and growth rate $\left(0.33-0.52 \mathrm{~d}^{-1}\right)$ at $15 \% \mathrm{CO}_{2}$ concentration. Ettlia sp. YC001 at $10 \% \mathrm{CO}_{2}$ achieved $3.1 \mathrm{~g} \mathrm{~L}^{-1}$ cell density and $80.0 \mathrm{mg} \mathrm{L}^{-1} \mathrm{~d}^{-1}$ lipid productivity, after 16-days of cultivation [79]. Montoya et al. [80] reported a high concentration of fatty acids and lipid productivity $(29.5 \mathrm{mg} / \mathrm{L} /$ day $)$ for C. vulgaris at a $\mathrm{CO}_{2}$ concentration of $8 \%(v / v)$. Nakanishi et al. [81] obtained maximum lipid productivity of $169.1 \mathrm{mg} / \mathrm{L} /$ day for Chlamydomonas sp. JSC4 strain at $4 \%(v / v)$ $\mathrm{CO}_{2}$ concentration, whereas for the species $D$. salina, growth inhibition was observed at $0.02 \mathrm{~mol} \mathrm{CO}_{2} / \mathrm{L}$ concentration or higher for Dunaliella salina. Bagchi and Mallick [82] reported that at $15 \%(v / v)$ of $\mathrm{CO}_{2}$ concentration, Scenedesmus Obliquus (Turpin) Kützing GA 45 stocked up $850 \mathrm{mg} / \mathrm{L}$ of lipid in 16 days. Hui et al. [83] observed a trend of reduced lipid productivity with increased $\mathrm{CO}_{2}$ concentration while studying the effect of varying $\mathrm{CO}_{2}$ concentration $(0.03-20 \%)$ in Tribonema minus. At $2 \% \mathrm{CO}_{2}$ aeration, maximum total lipid content was attained, and at $20 \% \mathrm{CO}_{2}$, total lipid content was at its least. However, the culture aerated at $0.03 \% \mathrm{CO}_{2}$ illustrated the second-lowest lipid content, signifying photosynthesis restraints due to the medium's shortage of carbon sources. Kao et al. [84] cultivated Chlorella sp. in synthetic media by aerating with industrial gaseous effluents rich in $\mathrm{CO}_{2}$. A maximum specific growth rate of $0.827 \mathrm{~d}^{-1}$ and lipid production of $0.961 \mathrm{~g}$ $\mathrm{L}^{-1}$ was obtained. Thus, gaseous effluents can be utilized to enhance biomass and lipid production as well as for $\mathrm{CO}_{2}$ biofixation.

Table 5. Different microalgae's response to varying $\mathrm{CO}_{2}$ concentration.

\begin{tabular}{|c|c|c|c|}
\hline Microalgae & Stress Condition & Result & Reference \\
\hline N. oculata & $2 \%$ and $15 \% \mathrm{CO}_{2}$ & Lipid productivity of 142 and $82 \mathrm{mg} \mathrm{L}^{-1} \mathrm{~d}^{-1}$ & [78] \\
\hline Nannochloropsis sp. & $15 \% \mathrm{CO}_{2}$ & $\begin{array}{l}\text { Increased biomass productivity }\left(0.39-1.43 \mathrm{gL}^{-1}\right) \text { and } \\
\text { growth rate }\left(0.33-0.52 \mathrm{~d}^{-1}\right)\end{array}$ & [14] \\
\hline Ettlia sp. YC001 & $10 \% \mathrm{CO}_{2}$ & $\begin{array}{l}3.1 \mathrm{~g} \mathrm{~L}^{-1} \text { cell density and } 80.0 \mathrm{mg} \mathrm{L}^{-1} \mathrm{~d}^{-1} \\
\text { lipid productivity }\end{array}$ & [79] \\
\hline C. vulgaris & $8 \% \mathrm{CO}_{2}$ & $29.5 \mathrm{mg} \mathrm{L}^{-1} \mathrm{~d}^{-1}$ lipid productivity & [80] \\
\hline Chlamydomonas sp. JSC4 & $4 \% \mathrm{CO}_{2}$ & $169.1 \mathrm{mg} \mathrm{L}^{-1} \mathrm{~d}^{-1}$ lipid productivity & [81] \\
\hline Scenedesmus Obliquus & $15 \% \mathrm{CO}_{2}$ & $850 \mathrm{mg} / \mathrm{L}$ of lipid in 16 days & [82] \\
\hline Tribonema minus & $(0.03-20 \%) \mathrm{CO}_{2}$ & Reduced lipid productivity with increased $\mathrm{CO}_{2}$ & [83] \\
\hline
\end{tabular}

Ying et al. [85] studied $\mathrm{pH}$ changes at different $\mathrm{CO}_{2}$ concentrations, leading to drastic $\mathrm{pH}$ changes which destroy enzymes involved in photosynthesis. The availability of a high level of $\mathrm{H}_{2} \mathrm{CO}_{3}$, transformed from the unused $\mathrm{CO}_{2}$, lowered the media's $\mathrm{pH}$, creating a hostile condition for the growth of microalgae. Additionally, the lowered $\mathrm{pH}$ hinders lipid synthesis's carbon assimilation due to the lowered bicarbonate concentration [8]. $\mathrm{pH}$ changes in microalgae cause diverse biochemical responses. In Chlorella, high $\mathrm{pH}$ 
hindered the cell division cycle, provoked the discharge of autospores and initiated TAG utilization [86].

$\mathrm{CO}_{2}$ concentration for microalgal growth and lipid accumulation is species-specific. In short, the increase in $\mathrm{CO}_{2}$ could help in the production and stock up of lipids in the microalgae for some species, but it might not be the same for other microalgae species. Supplying additional $\mathrm{CO}_{2}$ during phycoremediation of wastewater helps in lipid content enhancement [87]. In addition to $\mathrm{CO}_{2}$ concentration, it is crucial to estimate the optimum $\mathrm{pH}$ range for optimal biomass growth and lipid stock up in microalgae. When microalgae are provided with high $\mathrm{CO}_{2}$ concentration, a portion of the carbon is utilized for photosynthesis, whereas the remaining carbon is transformed into carbonic acid $\left(\mathrm{H}_{2} \mathrm{CO}_{3}\right) . \mathrm{H}_{2} \mathrm{CO}_{3}$ causes acidification changing metabolic pathways.

\subsubsection{Effect of Nutrients}

Microalgae require nutrients (nitrogen, phosphorus, iron, magnesium, sulfur, and silicon) for photosynthesis, respiration, cell division, intracellular transportation, and protein synthesis. Microalgae tend to stock up lipids during nutrient stress (Table 6). Tran et el. [88] investigated the effect of nitrogen deficiency in Chlorella vulgaris. They observed that Chlorella vulgaris accumulates a higher amount of lipids (TAGs). Converti et al. [42] reported that under nitrogen deficiency, the lipid yield enhanced to $15.31 \%$ for Nannochloropsis oculata and $16.41 \%$ for Chlorella vulgaris. Nitrogen deficiency in Nannochloropsis sp. can synthesize more TAGs and reduce polar lipids [89]. Nannochloropsis sp. F\&M-M24 illustrated maximum lipid productivity of $204 \mathrm{mg} \mathrm{L}^{-1} \mathrm{~d}^{-1}$ at nitrogen-deficient condition [90], whereas N. oceanica DUT01 illustrated maximum lipid productivity of $31 \mathrm{mg} \mathrm{L}^{-1} \mathrm{~d}^{-1}$ under nitrogen-rich conditions [45]. Other studies conducted by Hsieh and $\mathrm{Wu}$ [91], Praveenkumar et al. [92] and Li et al. [93] also reported similar results for various species of microalgae. Many previous studies examined that in most microalgae species nitrogen deficiency enhanced lipid accumulation (30-70\%) within 7-20 days [94]. Nitrogen deficiency for 9 days helped Monallantus salina to attain the maximum lipid concentration of $72 \%$. Botryococcus braunii attained $61.4 \%$, Chlorella vulgaris attained $57.9 \%$ and Nannochloropsis sp. attained 55\% lipid production during their lifetime, whereas Scenedesmus sp. and Chlorella sorokiniana could not attain maximum lipid content even after 7 and 14 days. Adams et al. [95] demonstrated that Chlorella vulgaris and Chlorella oleofaciens have more potential as biofuel feedstock species than Chlorella sorokiniana, Neochloris oleoabundans, Scenedesmus dimorphus, and S. naegleii as they react to slight stress, thus growing and accumulating lipids simultaneously. Lin and Lin [96] reported the highest biomass productivity in Scenedesmus rubescens by a mixture of urea and sodium nitrate.

Tao et al. [97] observed differences in lipid content and fatty acid composition for the microalgae species Chlorococcum ellipsoideum, Chlorococcum nivale, Chlorococcum tatrense, and Scenedesmus deserticola due to nitrate and urea deficiency. Yang et al. [98] demonstrated a significant increase in fatty acid yield for Chlamydomonas reinhardtii when the growth media were deficient in phosphorus or nitrogen. Phosphorus deficiency displays minor effects on the photosynthetic physiology and protein content of Chlamydomonas reinhardtii compared with nitrogen deficiency, and microalgae lessen the number of ribosomes to uphold the protein synthesis or polyphosphates storage [99]. Cordeiro et al. [100] studied the effects of phosphorus and nitrogen levels on the growth of species of Microcystis panniformis and Microcystis novacekii. They reported that the lipid accumulation had an inverse and direct correlation with nitrogen (35.8\%) and phosphorus concentration (31.7\%) for Microcystis panniformis and Microcystis novacekii, respectively. At the same time, Mata et al. [101] observed that increasing the nitrogen concentration up to 10-fold led to increased lipid productivity (47.4 mg/L/day) and content (33.5\%) for Dunaliella tertiolecta. Xin et al. [68] in Scenedesmus sp. reported maximum lipid accumulation of $53 \%$ under phosphate deficiency $\left(0.1 \mathrm{mg} \mathrm{L}^{-1}\right)$. Microalgae stock up phosphorus as polyphosphate during adequate nutrient conditions, which is then used up during nutrient-deficient conditions. 
Microalgae have verified their efficiency and effectiveness in enduring a high concentration of micronutrients. Various studies have demonstrated the increase in the lipid content of some microalgae species due to micronutrients stress. Liu et al. [102] demonstrated 3-7 folds enhanced lipid accumulation in Chlorella vulgaris under higher iron concentration than the control. Baky et al. [103] found enhanced lipid yield (28.12\%) with an increase in $\mathrm{FeCl}_{3}$ concentration of $20 \mathrm{mg} \mathrm{L}^{-1}$ when Scenedesmus obliquus was cultivated in N-9 medium. Singh et al. [46] observed that a low iron concentration of $3 \mathrm{mg} \mathrm{L}^{-1}$ decreased the lipid content and productivity of Ankistrodesmus falcatus, whereas enhanced lipid content and productivity were observed when iron concentration $\left(6 \mathrm{mg} \mathrm{L}^{-1}\right)$ increased. Ren et al. [104] studied the effect of $\mathrm{Fe}^{3+}(0-0.12 \mathrm{~g} / \mathrm{L}), \mathrm{Mg}^{2+}(0-0.73 \mathrm{~g} / \mathrm{L})$, and $\mathrm{Ca}^{2+}(0-0.98 \mathrm{~g} / \mathrm{L})$ on lipid accumulation in Scenedesmus sp. They reported that the addition of EDTA $(0-1 \mathrm{mg} / \mathrm{L})$ during cultivation increased total lipid content up to $28.2 \%$ and lipid productivity up to $29.7 \%$. Gorain et al. [105] observed enhanced lipid content (1.44-fold) when $100 \mathrm{mg} \mathrm{L}^{-1}$ magnesium was added in the media. Battah et al. [94], using manganese chloride $\left(\mathrm{MnCl}^{2}\right)$ at a concentration of $2 \mu \mathrm{M}, 10 \mu \mathrm{M}$, and $12 \mu \mathrm{M}$, evaluated the effect of $\mathrm{Mn}^{2+}$ and $\mathrm{Co}^{2+}$ on the lipid content of $C$. vulgaris. They observed that $\mathrm{MnCl}_{2}$ at $2 \mu \mathrm{M}, 10 \mu \mathrm{M}$, and $12 \mu \mathrm{M}$ concentration increased lipid content significantly by $14 \%, 16 \%$, and $15 \%$, respectively. In addition to that, Battah et al. [106] reported a 25\% increase in lipid content when cobalt nitrate was added in varying concentrations. Liu et al. [102] reported a 56.6\% increase in the total lipid content in C. vulgaris at five varying $\mathrm{Fe}^{3+}$ concentrations.

Nutrient stress is a practical and promising strategy exploited by researchers and industries to modify and regulate the biochemical pathways for lipid production and accumulation in microalgae [107]. During the early stages of microalgal growth, nutrientrich media lead to enhanced biomass productivity. However, deficiency of nutrients during the later stages of growth has detrimental effects, leading to the lipid stock up. During nitrogen deficiency, most microalgae exhibit enhanced lipid synthesis (TAGs) and protein biodegradation. The lipid enhancement mechanism induced by nutrient stress is not understood properly. Yet, nitrogen deficiency stimulates acyl hydrolase and phospholipid hydrolysis, demonstrating a reduction in the cellular content of thylakoid membranes and protein synthesis, ultimately reducing cell growth [108,109], thereby compromising the microalgal growth, biomass yield, and consequently affecting the lipid productivity [110]. Many studies investigated different species of microalgae for various nutrient deficiencies. In the growth media, nitrogen may be supplied in the form of nitrates, urea, and ammonium salts. The utilization of these nitrogen forms by microalgae might differ. Ammonia can be directly converted to amino acids, thus microalgae use it more efficiently than the other forms of nitrogen $[43,111]$. Changing the nitrogen source might cause a change in the amount of lipid accumulation and fatty acid composition. Metal ions also have numerous physiological functions influencing the metabolism and lipid accumulation of microalgae. $\mathrm{Ca}^{2+}$ is engaged in the signaling of environmental and developmental stimuli. $\mathrm{Mg}^{2+}$ is involved in triggering and mediating various biochemical reactions, i.e., regulating carbon fixation in chloroplasts in the Calvin cycle. Increasing $\mathrm{Mg}^{2+}$ can help Acetyl-CoA carboxylase, the key regulator of fatty acid synthesis, to enhance the neutral lipid content in microalgae.

\subsubsection{Effect of Salinity Stress}

Salinity stress in microalgae causes a difference in osmotic pressure, generating a stress response that alters their metabolic activity [112]. Different microalgae's response to salinity stress has been summarized in Table 7. Rao et al. [113] illustrated a 1.7-2.25-fold increase in palmitic acid's relative quantity and a 2-fold increase in oleic acid at high salinity concentration ( $34 \mathrm{mM}$ and $85 \mathrm{mM}$ ) for Botrycococcus braunii. Sharma et al. [114] reported that varying salt concentration in the microalgal growth medium increases the total lipid content and alters the lipid composition. Bartley et al. [115] studied the effect of salinity stress on the growth of Nannochloropsis salina. They examined it at a salt concentration of 34, 46, and 58 PSU. They reported the highest total fatty acid content of $36 \%$ dry tissue mass at 34 PSU. 
Salama et al. [44] observed the maximum lipid content of 37\% and 34\% for Chlamydomonas Mexicana and Scenedesmus obliquus, respectively, at a $25 \mathrm{mM} \mathrm{NaCl}$ concentration. They also reported the dominant fraction of fatty acids as linoleic acids (41\%) and oleic acids (41\%). Figler et al. [116] reported on the halotolerant species Coelastrum morus, which could thrive at $1000 \mathrm{mg} \mathrm{L}^{-1} \mathrm{NaCl}$ and remove a significant amount of nitrate in media with different N:P ratios and salt concentrations, although the growth of the species was negatively affected.

Table 6. Different microalgae responses to nutrient stress.

\begin{tabular}{|c|c|c|c|}
\hline Microalgae & Stress Condition & Result & Reference \\
\hline $\begin{array}{l}\text { Nannochloropsis oculata } \\
\text { Chlorella vulgaris }\end{array}$ & Nitrogen deficiency & $\begin{array}{l}\text { 15.31\% lipid yield for N. oculata and } 16.41 \% \\
\text { for C. vulgaris }\end{array}$ & [42] \\
\hline Nannochloropsis sp. FEM-M24 & Nitrogen-deficient condition & Lipid productivity of $204 \mathrm{mg} \mathrm{L}^{-1} \mathrm{~d}^{-1}$ & [90] \\
\hline $\begin{array}{l}\text { N.oceanica } \\
\text { DUT01 }\end{array}$ & Nitrogen-rich condition & $31 \mathrm{mg} \mathrm{L}^{-1} \mathrm{~d}^{-1}$ lipid productivity & [45] \\
\hline $\begin{array}{l}\text { Microcystis panniformis } \\
\text { Microcystis novacekii }\end{array}$ & Phosphorus and nitrogen & $\begin{array}{l}\text { Lipid accumulation had an inverse and } \\
\text { direct correlation with nitrogen and } \\
\text { phosphorus concentration }\end{array}$ & [100] \\
\hline Dunaliella tertiolecta & Nitrogen & $\begin{array}{c}10 \text { folds increased nitrogen led to lipid } \\
\text { productivity of } 47.4 \mathrm{mg} \mathrm{L}^{-1} \mathrm{~d}^{-1} \text { and content } \\
\text { of } 33.5 \%\end{array}$ & [101] \\
\hline Chlorella vulgaris & High iron & 3-7 folds enhanced lipid accumulation & {$[102]$} \\
\hline Ankistrodesmus falcatus & $3-6 \mathrm{mg} \mathrm{L}^{-1}$ iron & $\begin{array}{l}3 \mathrm{mg} \mathrm{L} \mathrm{L}^{-1} \text { decreased the lipid content and } \\
\text { productivity whereas } 6 \mathrm{mg} \mathrm{L}^{-1} \text { enhanced } \\
\text { lipid content and productivity }\end{array}$ & [46] \\
\hline
\end{tabular}

Table 7. Different microalgae responses to salinity.

\begin{tabular}{|c|c|c|c|}
\hline Microalgae & Stress Condition & Response & Reference \\
\hline $\begin{array}{c}\text { Botrycococcus braunii } \\
\text { N. oculata }\end{array}$ & $\begin{array}{l}\text { Salinity concentration of } 34 \\
\mathrm{mM} \text { and } 85 \mathrm{mM}\end{array}$ & $\begin{array}{l}\text { 1.7-2.25-fold increase in palmitic acid and } \\
\text { 2-fold increase in oleic acid at } 34 \mathrm{mM} \text { and } 85 \\
\mathrm{mM} \text { for B. braunii. For N. exican, rise in } \\
\text { temperature led to an enhanced lipid } \\
\text { production by } 2 \text {-fold }\end{array}$ & [113] \\
\hline Nannochloropsis salina & $\begin{array}{l}\text { Salt concentration of } 34,46, \\
\text { and } 58 \text { PSU }\end{array}$ & $\begin{array}{l}\text { Highest total fatty acids content of } 36 \% \text { dry } \\
\text { tissue mass at } 34 \text { PSU }\end{array}$ & [115] \\
\hline $\begin{array}{l}\text { Chlamydomonas mexicana } \\
\text { Scenedesmus obliquus }\end{array}$ & $25 \mathrm{mM} \mathrm{NaCl}$ & $\begin{array}{l}\text { Maximum lipid content of } 37 \% \text { and } 34 \% \text { for } \\
\text { C. mexicana and S. obliquus }\end{array}$ & [44] \\
\hline $\begin{array}{c}\text { C. vulgaris } \\
\text { Acutodesmus obliquus }\end{array}$ & $0.4 \mathrm{M} \mathrm{NaCl}$ & $\begin{array}{l}\text { Highest growth and lipid productivity } \\
\text { was observed }\end{array}$ & [117] \\
\hline Acutodesmus dimorphus & $200 \mathrm{mM} \mathrm{NaCl}$ & $33.40 \pm 2.29 \%$ lipid accumulation & [118] \\
\hline $\begin{array}{c}\text { Chlorella sorokiniana } \\
\text { CG12(KR905186) } \\
\text { Desmodesmus GS12(KR905187) }\end{array}$ & $\mathrm{NaCl}, \mathrm{KCl}, \mathrm{MgCl}_{2}$ and $\mathrm{CaCl}_{2}$ & $\begin{array}{c}\mathrm{CaCl}_{2} \text { improved up to } 40.02-44.97 \% \text { in } \\
\text { Chlorella sorokiniana CG12(KR905186) and } \\
\text { Desmodesmus GS12(KR905187) }\end{array}$ & [43] \\
\hline
\end{tabular}

Pandit et al. [117] reported that the maximum amount of lipids was $49 \%$ and $43 \%$ for C. vulgaris and Acutodesmus obliquus, respectively, at a concentration of $0.4 \mathrm{M} \mathrm{NaCl}$, whereas Chokshi et al. [118] observed $33.40 \pm 2.29 \%$ lipid accumulation at $200 \mathrm{mM} \mathrm{NaCl}$ for Acutodesmus dimorphus, which enhanced up to $43 \%$ when salinity stress extended up to 3 days. Srivastava et al. [119] studied the effect of lipid accumulation in microalgae with different salts $\left(\mathrm{NaCl}, \mathrm{KCl}, \mathrm{MgCl}_{2}\right.$ and $\left.\mathrm{CaCl}_{2}\right)$. They reported that $\mathrm{CaCl}_{2}$ had the maximum effect on lipid production, improving up to $40.02 \%$ and $44.97 \%$ in Chlorella sorokiniana CG12(KR905186) and Desmodesmus GS12(KR905187), respectively, thereby indicating that $\mathrm{Ca}^{2+}$ demonstrates an authoritative function in cell signaling under salinity stress leading to an enhancement in lipid synthesis. 
Hence, the addition of salts is a simple, efficient strategy to enhance lipid accumulation while reducing non-target microalgae invasion, as salts perform a vital function in the physiological and biochemical pathways of growth and fatty acid metabolism in microalgae.

\section{Integration of Wastewater Treatment, Enhanced Biomass, and Lipid Production Strategies}

Microalgae cultivation for simultaneous lipid production and wastewater treatment is a sustainable and economical route (Figure 2). Various sources of wastewater are utilized for the cultivation of microalgae. The various sources of wastewater include but are not limited to; domestic wastewater [120], industrial and agro-industrial wastes [121], swine wastewater [122], and stabilization lagoon from sanitation facilities [123]. Several previous studies have demonstrated either biomass productivity or enhanced lipid productivity in addition to wastewater treatment. Nevertheless, many studies now integrate wastewater treatment and enhanced biomass and lipid production strategies. Fields et al. [124] stated that high lipid productivity could be attained by a high concentration of inorganic carbon and nutrient stress. When light is sufficient, and nitrogen is deficient, photosynthetic carbon fixation continues while growth ceases. This, consequently, enhances the C:N ratio and TAG productivity.

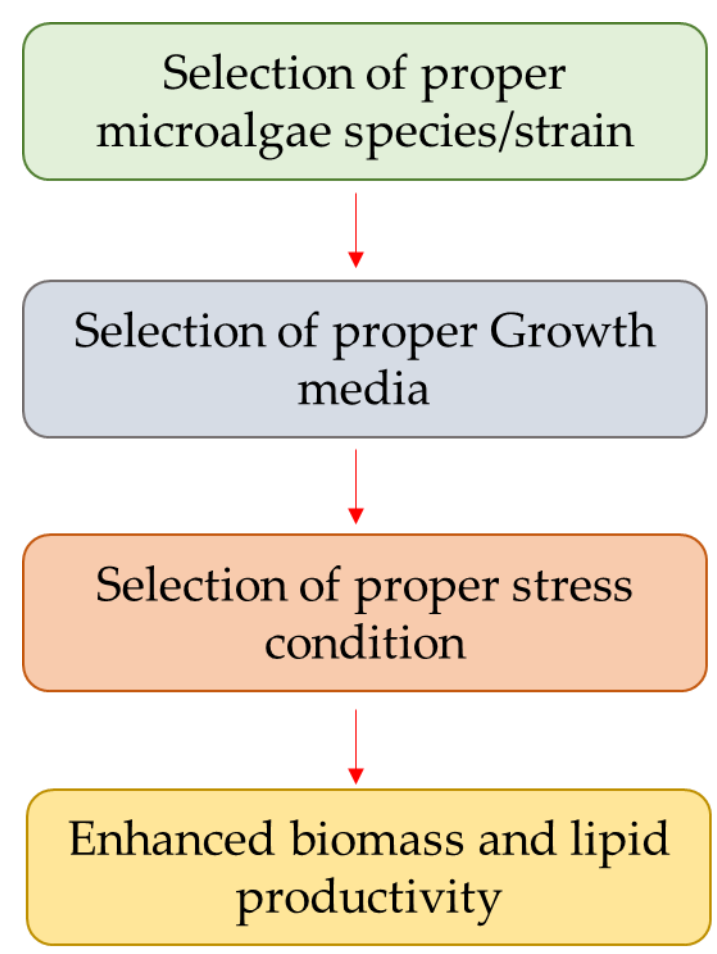

Figure 2. Showing the stepwise selection of proper conditions for enhanced biomass and lipid productivity.

Zhou et al. [125] identified different microalgae capable of growing in concentrated municipal wastewater at a light intensity of $50 \mu \mathrm{mol} \mathrm{m}^{-2} \mathrm{~s}^{-1}$. They observed that Chlorella sp., Heynigia sp., Hindakia sp., Micractinium sp. and Scenedesmus sp. could adapt to the concentrated municipal wastewater. Additionally, high growth rates $(231-275 \mathrm{mg} / \mathrm{L} / \mathrm{d})$ and higher lipid content (28.9-33.5\%) compared with other species were witnessed. They concluded that the microalgae that showed high biomass productivity and lipid content could acclimatize themselves to the concentrated municipal wastewater and lighting conditions provided for their growth, lipid enhancement, and nutrient removal. In another study, Li et al. [126] investigated the effect of light intensity on biomass accumulation, wastewater treatment, and biodiesel productivity for Chlorella kessleri and Chlorella protothecoide. The optimum light intensity for C. kessleri and C. protothecoide was $120 \mu \mathrm{mol} \mathrm{m}^{-2} \mathrm{~s}^{-1}$ and 
$30 \mu \mathrm{mol} \mathrm{m} \mathrm{m}^{-2} \mathrm{~s}^{-1}$, respectively. They reported the highest biodiesel content of $24.19 \%$ and $19.48 \%$ C. kessleri and C. protothecoide, respectively, with the main components being 16-C and 18-C FAME.

Cabanelas et al. [127] evaluated the growth of microalgae using domestic wastewater amended with glycerol. The best results were attained with the highest glycerol supplementation $(50 \mathrm{mM})$ when aerated with $2.5 \% \mathrm{CO}_{2}$, photoperiod of 12:12 light/dark cycles, the luminance of $174 \mu \mathrm{E} / \mathrm{m}^{2} / \mathrm{s}$ and incubation at $25 \pm 1{ }^{\circ} \mathrm{C}$. At this condition, Chlorella vulgaris and Botryococcus terribilis showed biomass productivity of 118 and $282 \mathrm{mg} \mathrm{L}^{-1} \mathrm{~d}^{-1}$, which produced about 18 and $35 \mathrm{mg} \mathrm{L}^{-1} \mathrm{~d}^{-1}$ lipids, respectively.

Aketo et al. [29] observed the lipid productivity of various microalgal strains in municipal wastewater. They reported Parachlorella kessleri NKG021201 removed 99\% nitrogen and $82 \%$ phosphorous from the wastewater along with $101 \pm 1 \mathrm{mg} / \mathrm{L} / \mathrm{d}$ biomass productivity and $39 \pm 1 \%$ lipid content. P. kessleri NKG021201 was cultured again at optimal culture conditions in municipal wastewater to further enhance the biomass productivity and lipid content. The biomass productivity and lipid content enhanced to $147 \pm 1 \mathrm{mg} / \mathrm{L} / \mathrm{d}$ and $56 \pm 1 \mathrm{mg} / \mathrm{L} / \mathrm{d}$, respectively, when the culture condition was changed to $1 \% \mathrm{NaCl}$, $0.8 \mathrm{~L} / \mathrm{L} / \mathrm{min}$ aeration with $4 \% \mathrm{CO}_{2}, 30{ }^{\circ} \mathrm{C}$ and continuous illumination at $200 \mu \mathrm{mol} / \mathrm{m}^{2} / \mathrm{s}$. Singh and Ummalyma [128] observed enhanced biomass (450 $\left.\mathrm{mg} \mathrm{L}^{-1}\right)$ and lipid yield of $129 \mathrm{mg} \mathrm{L}^{-1}(28 \%)$ when Chlorococcum sp. $S L 7 B$ was grown in river water contaminated with pharmaceutical effluent. The Chlorococcum sp. SL7B was maintained at $26 \pm 2{ }^{\circ} \mathrm{C}$, $40.5 \mu \mathrm{mol}$ photons $\mathrm{m}^{-2} \mathrm{~s}^{-1}$ at a light/dark cycle of 14:10 h. They concluded that microalgae grown on polluted river water exhibited enhanced biomass and lipid production along with organic pollutant removal.

The utilization of microalgae for the treatment of wastewater is known as phycoremediation. Usually, the wastewater stream has a high content of nutrients and organic matter, but wastewater sources have varying nutrient concentrations which may be toxic to microalgae. Collos and Harrison [129] examined the effect of nitrogen concentration from ammonia on six microalgae classes. For Chlorophyceae they exhibited an optimal concentration of $7600 \mu \mathrm{M}$ and toxic concentration of 39,000 $\mu \mathrm{M}$. Improvement in nutrient tolerance can be achieved by strains acclimation in culture media. Moreover, they concluded that further research is necessary as ammonium and ammonia toxicity can vary with other parameters (light, $\mathrm{pH}$, temperature). Silambarasan et al. [21] reported that for the consortium of Chlorella sp. and Scenedesmus sp. when grown in 75\% diluted wastewater, the highest biomass of $1.78 \mathrm{~g} \mathrm{~L}^{-1}$ and lipid content of $34.83 \%$ dry cell weight were obtained. The reported algal consortium was proficient in removing $96 \%$ nitrate removal, $98 \%$ ammonium, 95\% phosphate, and 94\% total nitrogen from the 75\% diluted wastewater. Han et al. [22] observed that $0.33-0.38 \mathrm{~g} \mathrm{~L}^{-1}$ of total lipid was yielded by Scenedesmus obliquus when cultivated in municipal wastewater along with $98.9-99.8 \%$ of nitrogen removal and 83.1-97.6\% of phosphorus removal. Scenedesmus obliquus was supplied with 14,500 lx light intensity, $97 \mathrm{mg} \mathrm{L}^{-1}$ nitrogen, $11 \mathrm{mg} \mathrm{L}^{-1}$ phosphorus, and 9.8\% $\mathrm{CO}_{2}$.

Several studies used pretreated or raw industrial wastewater for microalgae growth $[123,130]$. However, a few studies also suggested that microalgae may be utilized as a tertiary treatment to eliminate residual organic and inorganic effluent contamination [131]. Either way, both wastewater treatment and lipid concentration in microalgae can be obtained.

Microalgae biorefineries corresponds to an effective green strategy for synchronous wastewater treatment and bioenergy production [132-134]. Silkina et al. [135] developed a bio-refinery approach cultivating up to $1.5 \mathrm{~m}^{3}$ Nannochloropsis oceanica biomass in pilot scale where they witnessed $99 \%$ of nitrogen and phosphorus uptake by microalgal cultures. A similar pilot scale biorefinery approach was conducted with Nephroselmis sp. KGE8, Acutodesmus obliquus KGE 17 and Acutodesmus obliquus KGE32 microalgae [136]. In a pilot scale study of integrated biofuel production and wastewater treatment, the process simulation provided an estimated 82.77-140.58 tons/ha/year $\mathrm{CO}_{2}$ sequestration with 63-107 tons/ha/year potential biomass production. The integrated process was reported 
to significantly enhance the energy balance and economics of the wastewater treatment plant [137].

Therefore, it can be concluded that a proper microalgae strain should be acclimated in wastewater integrated with the favorable lipid enhancement strategies and culture conditions to simultaneously treat wastewater and enhance biomass and lipid productivity for biofuel production.

\section{Conclusions and Future Recommendation}

Microalgae are efficient organisms for wastewater treatment, and when combined with proper culture conditions, humankind can reap benefits such as high biomass and lipid productivity. Diverse microalgae have diverse optimal culture conditions. It is essential to comprehend the intricacies and flexibilities of the culture condition. Synchronizing the culture condition can facilitate maximizing biomass production and lipid accumulation in conjunction with wastewater treatment. It is crucial to adopt a less expensive and efficient sustainable culture media to reduce cultivation costs. Thus, this review provided insight on the influence of culture media and conditions to address synchronous microalgae biomass and lipid enhancement and phycoremediation. Most of the reviewed studies presented are investigations either on lipid enhancement or wastewater treatment by microalgae; there are very few studies available on synchronous microalgal lipid enhancement and wastewater treatment. Laboratory and pilot scale examinations and economic feasibility analyses to address synchronous microalgae biomass and lipid enhancement are essential to substantiate its application.

Author Contributions: Conceptualization, M.M. and V.B.B.; writing-original draft preparation, V.B.B.; writing-review and editing, V.B.B. and M.M. All authors have read and agreed to the published version of the manuscript.

Funding: This research received no external funding.

Institutional Review Board Statement: Not applicable

Informed Consent Statement: Not applicable

Conflicts of Interest: The authors declare no conflict of interest.

\section{References}

1. Hemalatha, M.; Mohan, S.V. Microalgae cultivation as tertiary unit operation for treatment of pharmaceutical wastewater associated with lipid production. Bioresour. Technol. 2016, 215, 117-122. [CrossRef] [PubMed]

2. Khalid, A.A.H.; Yaakob, Z.; Abdullah, S.R.S.; Takriff, M.S. Assessing the feasibility of microalgae cultivation in agricultural wastewater: The nutrient characteristics. Environ. Technol. Innov. 2019, 15, 100402. [CrossRef]

3. Cheah, W.Y.; Ling, T.C.; Show, P.L.; Juan, J.C.; Chang, J.-S.; Lee, D.-J. Cultivation in wastewaters for energy: A microalgae platform. Appl. Energy 2016, 179, 609-625. [CrossRef]

4. Pittman, J.K.; Dean, A.; Osundeko, O. The potential of sustainable algal biofuel production using wastewater resources. Bioresour. Technol. 2011, 102, 17-25. [CrossRef]

5. Lundquist, T.J.; Woertz, I.C.; Quinn, W.M.T.; Benemann, J. A Realistic Technology and Engineering Assessment of Algae Biofuel Production. Available online: https://digitalcommons.calpoly.edu/cgi/viewcontent.cgi?article=1189\&context=cenv_fac (accessed on 5 October 2021).

6. Chen, G.; Zhao, L.; Qi, Y. Enhancing the productivity of microalgae cultivated in wastewater toward biofuel production: A critical review. Appl. Energy 2015, 137, 282-291. [CrossRef]

7. Demirbas, A.; Demirbas, M.F. Importance of algae oil as a source of biodiesel. Energy Convers. Manag. 2011, 52, 163-170. [CrossRef]

8. Zhu, L.D.; Li, Z.H.; Hiltunen, E. Strategies for Lipid Production Improvement in Microalgae as a Biodiesel Feedstock. BioMed Res. Int. 2016, 2016, 8792548. [CrossRef]

9. Min, M.; Wang, L.; Li, Y.; Mohr, M.J.; Hu, B.; Zhou, W.; Chen, P.; Ruan, R. Cultivating Chlorella sp. in a Pilot-Scale Photobioreactor Using Centrate Wastewater for Microalgae Biomass Production and Wastewater Nutrient Removal. Appl. Biochem. Biotechnol. 2011, 165, 123-137. [CrossRef]

10. Mar, C.C.; Fan, Y.; Li, F.-L.; Hu, G.-R. Bioremediation of wastewater from edible oil refinery factory using oleaginous microalga Desmodesmus sp. S1. Int. J. Phytoremediation 2016, 18, 1195-1201. [CrossRef] 
11. Daneshvar, E.; Antikainen, L.; Koutra, E.; Kornaros, M.; Bhatnagar, A. Investigation on the feasibility of Chlorella vulgaris cultivation in a mixture of pulp and aquaculture effluents: Treatment of wastewater and lipid extraction. Bioresour. Technol. 2018, 255, 104-110. [CrossRef]

12. Chinnasamy, S.; Bhatnagar, A.; Hunt, R.W.; Das, K.C. Microalgae cultivation in a from poultry litter anaerobic digestion. Bioresour. Technol. 2010, 102, 10841-10848.

13. Hongyang, S.; Yalei, Z.; Chunmin, Z.; Xuefei, Z.; Jinpeng, L. Cultivation of Chlorella pyrenoidosa in soybean processing wastewater. Bioresour. Technol. 2011, 102, 9884-9890. [CrossRef]

14. Jiang, L.; Luo, S.; Fan, X.; Yang, Z.; Guo, R. Biomass and lipid production of marine microalgae using municipal wastewater and high concentration of $\mathrm{CO}_{2}$. Appl. Energy 2011, 88, 3336-3341. [CrossRef]

15. Singh, M.; Reynolds, D.L.; Das, K.C. Microalgal system for treatment of effluent wastewater dominated by carpet mill effluents for biofuel applications. Bioresour. Technol. 2011, 101, 3097-3105.

16. Wu, L.F.; Chen, P.C.; Huang, A.P.; Lee, C.M. The feasibility of biodiesel production by microalgae using industrial wastewater. Bioresour. Technol. 2012, 113, 14-18. [CrossRef]

17. Komolafe, O.; Orta, S.B.V.; Monje-Ramirez, I.; Noguez, I.Y.; Harvey, A.; Ledesma, M.T.O. Biodiesel production from indigenous microalgae grown in wastewater. Bioresour. Technol. 2014, 154, 297-304. [CrossRef] [PubMed]

18. Ramanna, L.; Guldhe, A.; Rawat, I.; Bux, F. The optimization of biomass and lipid yields of Chlorella sorokiniana when using wastewater supplemented with different nitrogen sources. Bioresour. Technol. 2014, 168, 127-135. [CrossRef]

19. Ansari, F.A.; Singh, P.; Guldhe, A.; Bux, F. Microalgal cultivation using aquaculture wastewater: Integrated biomass generation and nutrient remediation. Algal Res. 2017, 21, 169-177. [CrossRef]

20. Hernández-García, A.; Velásquez-Orta, S.B.; Novelo, E.; Yáñez-Noguez, I.; Monje-Ramírez, I.; Ledesma, M.T.O. Wastewaterleachate treatment by microalgae: Biomass, carbohydrate and lipid production. Ecotoxicol. Environ. Saf. 2019, 174, 435-444. [CrossRef]

21. Silambarasan, S.; Logeswari, P.; Sivaramakrishnan, R.; Incharoensakdi, A.; Cornejo, P.; Kamaraj, B.; Chi, N.T.L. Removal of nutrients from domestic wastewater by microalgae coupled to lipid augmentation for biodiesel production and influence of deoiled algal biomass as biofertilizer for Solanum lycopersicum cultivation. Chemosphere 2021, 268, 129323. [CrossRef]

22. Han, W.; Jin, W.; Li, Z.; Wei, Y.; He, Z.; Chen, C.; Qin, C.; Chen, Y.; Tu, R.; Zhou, X. Cultivation of microalgae for lipid production using municipal wastewater. Process. Saf. Environ. Prot. 2021, 155, 155-165. [CrossRef]

23. Vitova, M.; Bisova, K.; Kawano, S.; Zachleder, V. Accumulation of energy reserves in algae: From cell cycles to biotechnological applications. Biotechnol. Adv. 2015, 33, 1204-1218. [CrossRef]

24. Shah, S.H.; Raja, I.A.; Rizwan, M.; Rashid, N.; Mahmood, Q.; Shah, F.A.; Pervez, A. Potential of microalgal biodiesel production and its sustainability perspectives in Pakistan. Renew. Sustain. Energy Rev. 2018, 81, 76-92. [CrossRef]

25. Taher, H.; Al-Zuhair, S.; Al-Marzouqi, A.; Haik, Y.; Farid, M. Growth of microalgae using CO2 enriched air for biodiesel production in supercritical CO2. Renew. Energy 2015, 82, 61-70. [CrossRef]

26. Han, S.-F.; Jin, W.-B.; Tu, R.-J.; Wu, W. Biofuel production from microalgae as feedstock: Current status and potential. Crit. Rev. Biotechnol. 2013, 35, 255-268. [CrossRef]

27. Okoro, V.; Azimov, U.; Munoz, J.; Hernandez, H.; Phan, A.N. Microalgae cultivation and harvesting: Growth performance and use of flocculants-A review. Renew. Sustain. Energy Rev. 2019, 115, 109364. [CrossRef]

28. Yamaguchi, K.; Nakano, H.; Murakami, M.; Konosu, S.; Nakayama, O.; Kanda, M.; Nakamura, A.; Iwamoto, H. Lipid Composition of a Green Alga, Botryococcus braunii. Agric. Bioi. Chem. 1987, 51, 493-498.

29. Aketo, T.; Hoshikawa, Y.; Nojima, D.; Yabu, Y.; Maeda, Y.; Yoshino, T.; Takano, H.; Tanaka, T. Selection and characterization of microalgae with potential for nutrient removal from municipal wastewater and simultaneous lipid production. J. Biosci. Bioeng. 2020, 129, 565-572. [CrossRef]

30. Ruangsomboon, S. Effect of light, nutrient, cultivation time and salinity on lipid production of newly isolated strain of the green microalga, Botryococcus braunii KMITL 2. Bioresour. Technol. 2012, 109, 261-265. [CrossRef] [PubMed]

31. Remmers, I.M.; Wijffels, R.H.; Barbosa, M.J.; Lamers, P.P. Can We Approach Theoretical Lipid Yields in Microalgae? Trends Biotechnol. 2018, 36, 265-276. [CrossRef]

32. Zhang, H.; Wang, W.; Li, Y.; Yang, W.; Shen, G. Mixotrophic cultivation of Botryococcus braunii. Biomass- Bioenergy 2011, 35, 1710-1715. [CrossRef]

33. Toledo-Cervantes, A.; Morales, M.; Novelo, E.; Revah, S. Carbon dioxide fixation and lipid storage by Scenedesmus obtusiusculus Bioresour. Technol. 2013, 130, 652-658. [CrossRef] [PubMed]

34. Nascimento, I.A.; Cabanelas, I.T.D.; dos Santos, J.N.; Nascimento, M.A.; Sousa, L.; Sansone, G. Biodiesel yields and fuel quality as criteria for algal-feedstock selection: Effects of $\mathrm{CO}_{2}$-supplementation and nutrient levels in cultures. Algal Res. 2015, 8, 53-60. [CrossRef]

35. Ge, Y.; Liu, J.; Tian, G. Growth characteristics of Botryococcus braunii 765 under high CO2 concentration in photobioreactor. Bioresour. Technol. 2011, 102, 130-134. [CrossRef]

36. Mehrabadi, A.; Craggs, R.; Farid, M.M. Biodiesel production potential of wastewater treatment high rate algal pond biomass. Bioresour. Technol. 2016, 221, 222-233. [CrossRef] 
37. Yeh, K.L.; Chang, J.S. Nitrogen starvation strategies and photobioreactor design for enhancing lipid content and lipid production of a newly isolated microalga Chlorella vulgaris ESP-31: Implications for biofuels. Biotechnol. J. 2011, 6, 1358-1366. [CrossRef] [PubMed]

38. Yang, J.; Xu, M.; Zhang, X.; Hu, Q.; Sommerfeld, M.; Chen, Y. Life-cycle analysis on biodiesel production from microalgae: Water footprint and nutrients balance. Bioresour. Technol. 2011, 102, 159-165. [CrossRef] [PubMed]

39. Saranya, D.; Shanthakumar, S. Green microalgae for combined sewage and tannery effluent treatment: Performance and lipid accumulation potential. J. Environ. Manag. 2019, 241, 167-178. [CrossRef] [PubMed]

40. Krzemińska, I.; Oleszek, M.; Wiącek, D. Liquid Anaerobic Digestate as a Source of Nutrients for Lipid and Fatty Acid Accumulation by Auxenochlorella Protothecoides. Molecules 2019, 24, 3582. [CrossRef] [PubMed]

41. Gonçalves, A.L.; Pires, J.C.M.; Simões, M. A review on the use of microalgal consortia for wastewater treatment. Algal Res. 2017, 24, 403-415. [CrossRef]

42. Converti, A.; Casazza, A.A.; Ortiz, E.Y.; Perego, P.; Del Borghi, M. Effect of temperature and nitrogen concentration on the growth and lipid content of Nannochloropsis oculata and Chlorella vulgaris for biodiesel production. Chem. Eng. Process. Process. Intensif. 2009, 48, 1146-1151. [CrossRef]

43. Xin, L.; Hu, H.Y.; Ke, G.; Sun, Y.X. Effects of different nitrogen and phosphorus concentrations on the growth, nutrient uptake, and lipid accumulation of a freshwater microalga Scenedesmus sp. Bioresour. Technol. 2010, 101, 5494-5500. [CrossRef]

44. Salama, E.-S.; Kim, H.-C.; Abou-Shanab, R.; Ji, M.-K.; Oh, Y.-K.; Kim, S.-H.; Jeon, B.-H. Biomass, lipid content, and fatty acid composition of freshwater Chlamydomonas mexicana and Scenedesmus obliquus grown under salt stress. Bioprocess Biosyst. Eng. 2013, 36, 827-833. [CrossRef]

45. Wan, C.; Bai, F.-W.; Zhao, X.-Q. Effects of nitrogen concentration and media replacement on cell growth and lipid production of oleaginous marine microalga Nannochloropsis oceanica DUT01. Biochem. Eng. J. 2013, 78, 32-38. [CrossRef]

46. Singh, P.; Guldhe, A.; Kumari, S.; Rawat, I.; Bux, F. Investigation of combined effect of nitrogen, phosphorus and iron on lipid productivity of microalgae Ankistrodesmus falcatus KJ671624 using response surface methodology. Biochem. Eng. J. 2015, 94, 22-29. [CrossRef]

47. Álvarez-Díaz, P.D.; Ruiz, J.; Arbib, Z.; Barragán, J.; Garrido-Pérez, M.C.; Perales, J.A. Freshwater microalgae selection for simultaneous wastewater nutrient removal and lipid production. Algal Res. 2017, 24, 477-485. [CrossRef]

48. García, L.M.; Gariépy, Y.; Barnabé, S.; Raghavan, G. Effect of environmental factors on the biomass and lipid production of microalgae grown in wastewaters. Algal Res. 2019, 41, 101521. [CrossRef]

49. Patel, A.K.; Joun, J.; Sim, S.J. A sustainable mixotrophic microalgae cultivation from dairy wastes for carbon credit, bioremediation and lucrative biofuels. Bioresour. Technol. 2020, 313, 123681. [CrossRef]

50. Poh, Z.L.; Kadir, W.N.A.; Lam, M.K.; Uemura, Y.; Suparmaniam, U.; Lim, J.W.; Show, P.L.; Lee, K.T. The effect of stress environment towards lipid accumulation in microalgae after harvesting. Renew. Energy 2020, 154, 1083-1091. [CrossRef]

51. Lu, M.-M.; Gao, F.; Li, C.; Yang, H.-L. Response of microalgae Chlorella vulgaris to $\mathrm{Cr}$ stress and continuous $\mathrm{Cr}$ removal in a membrane photobioreactor. Chemosphere 2021, 262, 128422. [CrossRef]

52. Wahidin, S.; Idris, A.; Shaleh, S.R.M. The influence of light intensity and photoperiod on the growth and lipid content of microalgae Nannochloropsis sp. Bioresour. Technol. 2013, 129, 7-11. [CrossRef]

53. Hallenbeck, P.C.; Grogger, M.; Mraz, M.; Veverka, D. The use of Design of Experiments and Response Surface Methodology to optimize biomass and lipid production by the oleaginous marine green alga, Nannochloropsis gaditana in response to light intensity, inoculum size and CO2. Bioresour. Technol. 2015, 184, 161-168. [CrossRef]

54. Guo, X.; Su, G.; Li, Z.; Chang, J.; Zeng, X.; Sun, Y.; Lu, Y.; Lin, L. Light intensity and N/P nutrient affect the accumulation of lipid and unsaturated fatty acids by Chlorella sp. Bioresour. Technol. 2015, 191, 385-390. [CrossRef] [PubMed]

55. He, Q.; Yang, H.; Wu, L.; Hu, C. Effect of light intensity on physiological changes, carbon allocation and neutral lipid accumulation in oleaginous microalgae. Bioresour. Technol. 2015, 191, 219-228. [CrossRef] [PubMed]

56. Pal, D.; Khozin-Goldberg, I.; Cohen, Z.; Boussiba, S. The effect of light, salinity, and nitrogen availability on lipid production by Nannochloropsis sp. Appl. Microbiol. Biotechnol. 2011, 90, 1429-1441. [CrossRef] [PubMed]

57. Liu, J.; Yuan, C.; Hu, G.; Li, F. Effects of Light Intensity on the Growth and Lipid Accumulation of Microalga Scenedesmus sp. 11-1 Under Nitrogen Limitation. Appl. Biochem. Biotechnol. 2012, 166, 2127-2137. [CrossRef]

58. Takeshita, T.; Ota, S.; Yamazaki, T.; Hirata, A.; Zachleder, V.; Kawano, S. Starch and lipid accumulation in eight strains of six Chlorella species under comparatively high light intensity and aeration culture conditions. Bioresour. Technol. 2014, 158, 127-134. [CrossRef]

59. Liao, Q.; Sun, Y.; Huang, Y.; Xia, A.; Fu, Q.; Zhu, X. Simultaneous enhancement of Chlorella vulgaris growth and lipid accumulation through the synergy effect between light and nitrate in a planar waveguide flat-plate photobioreactor. Bioresour. Technol. 2017, 243, 528-538. [CrossRef]

60. Breuer, G.; Lamers, P.; Martens, D.E.; Draaisma, R.B.; Wijffels, R.H. Effect of light intensity, pH, and temperature on triacylglycerol (TAG) accumulation induced by nitrogen starvation in Scenedesmus obliquus. Bioresour. Technol. 2013, 143, 1-9. [CrossRef]

61. Teo, C.L.; Atta, M.; Bukhari, A.; Taisir, M.; Yusuf, A.M.; Idris, A. Enhancing growth and lipid production of marine microalgae for biodiesel production via the use of different LED wavelengths. Bioresour. Technol. 2014, 162, 38-44. [CrossRef]

62. Das, P.; Lei, W.; Aziz, S.S.; Obbard, J.P. Enhanced algae growth in both phototrophic and mixotrophic culture under blue light. Bioresour. Technol. 2011, 102, 3883-3887. [CrossRef] [PubMed] 
63. Hultberg, M.; Jönsson, H.L.; Bergstrand, K.-J.; Carlsson, A.S. Impact of light quality on biomass production and fatty acid content in the microalga Chlorella vulgaris. Bioresour. Technol. 2014, 159, 465-467. [CrossRef]

64. Rai, M.P.; Gautom, T.; Sharma, N. Effect of Salinity, pH, Light Intensity on Growth and Lipid Production of Microalgae for Bioenergy Application. Online J. Biol. Sci. 2015, 15, 260-267. [CrossRef]

65. Wong, Y.-K.; Ho, Y.H.; Ho, K.C.; Leung, H.M.; Chow, K.P.; Yung, K.K.L. Effect of different light sources on algal biomass and lipid production in internal leds-illuminated photobioreactor. J. Mar. Biol. Aquacult. 2016, 2, 1-8. [CrossRef]

66. Severes, A.; Hegde, S.; D'souza, L.; Hedge, S. Use of light emitting diodes (LEDs) for enhanced lipid production in microalgaebased biofuels. J. Photochem. Photobiol. B. 2017, 170, 235-240. [CrossRef] [PubMed]

67. Solovchenko, A.E.; Ismagulova, T.T.; Lukyanov, A.A.; Vasilieva, S.G.; Konyukhov, I.V.; Pogosyan, S.I.; Lobakova, E.S.; Gorelova, O.A. Luxury phosphorus uptake in microalgae. J. Appl. Phycol. 2019, 31, 2755-2770. [CrossRef]

68. Xin, L.; Hong-Ying, H.; Yu-Ping, Z. Growth and lipid accumulation properties of a freshwater microalga Scenedesmus sp. under different cultivation temperature. Bioresour. Technol. 2011, 102, 3098-3102. [CrossRef]

69. Dickinson, S.; Mientus, M.; Frey, D.; Amini-Hajibashi, A.; Ozturk, S.; Shaikh, F.; Sengupta, D.; El-Halwagi, M.M. A review of biodiesel production from microalgae. Clean Technol. Environ. Policy 2017, 19, 637-668. [CrossRef]

70. Subhash, G.V.; Rohit, M.; Devi, M.P.; Swamy, Y.; Mohan, S.V. Temperature induced stress influence on biodiesel productivity during mixotrophic microalgae cultivation with wastewater. Bioresour. Technol. 2014, 169, 789-793. [CrossRef]

71. Bohnenberger, J.; Crossetti, L.O. Influence of temperature and nutrient content on lipid production in freshwater microalgae cultures. An. Acad. Bras. Ciências 2014, 86, 1239-1248. [CrossRef]

72. Freire, I.; Cortina-Burgueño, A.; Grille, P.; Arizcun, M.A.; Abellán, E.; Segura, M.; Sousa, F.W.; Otero, A. Nannochloropsis limnetica: A freshwater microalga for marine aquaculture. Aquaculture 2016, 459, 124-130. [CrossRef]

73. Menegol, T.; Diprat, A.B.; Rodrigues, E.; Rech, R. Effect of temperature and nitrogen concentration on biomass composition of Heterochlorella luteoviridis. Food Sci. Technol. 2017, 37, 28-37. [CrossRef]

74. Wei, L.; Huang, X.; Huang, Z. Temperature effects on lipid properties of microalgae Tetraselmis subcordiformis and Nannochloropsis oculata as biofuel resources. Chin. J. Oceanol. Limnol. 2015, 33, 99-106. [CrossRef]

75. Renaud, S.M.; Thinh, L.-V.; Lambrinidis, G.; Parry, D.L. Effect of temperature on growth, chemical composition and fatty acid composition of tropical Australian microalgae grown in batch cultures. Aquaculture 2002, 211, 195-214. [CrossRef]

76. Los, D.A.; Murata, N. Membrane fluidity and its roles in the perception of environmental signals. Biochim. Biophys. Acta Biomembr. 2004, 1666, 142-157. [CrossRef]

77. Singh, S.P.; Singh, P. Effect of CO2 concentration on algal growth: A review. Renew. Sustain. Energy Rev. 2014, 38, 172-179. [CrossRef]

78. Chiu, S.-Y.; Kao, C.-Y.; Tsai, M.-T.; Ong, S.-C.; Chen, C.-H.; Lin, C.-S. Lipid accumulation and CO2 utilization of Nannochloropsis oculata in response to CO2 aeration. Bioresour. Technol. 2009, 100, 833-838. [CrossRef]

79. Yoo, C.; Choi, G.-G.; Kim, S.-C.; Oh, H.-M. Ettlia sp. YC001 showing high growth rate and lipid content under high CO2. Bioresour. Technol. 2013, 127, 482-488. [CrossRef]

80. Montoya, E.Y.O.; Casazza, A.; Aliakbarian, B.; Perego, P.; de Carvalho, J.C.M.; Converti, A. Production of Chlorella vulgaris as a source of essential fatty acids in a tubular photobioreactor continuously fed with air enriched with $\mathrm{CO} 2$ at different concentrations. Biotechnol. Prog. 2014, 30, 916-922. [CrossRef]

81. Nakanishi, A.; Aikawa, S.; Ho, S.-H.; Chen, C.-Y.; Chang, J.-S.; Hasunuma, T.; Kondo, A. Development of lipid productivities under different CO2 conditions of marine microalgae Chlamydomonas sp. JSC4. Bioresour. Technol. 2014, 152, 247-252. [CrossRef]

82. Bagchi, S.K.; Mallick, N. Carbon dioxide biofixation and lipid accumulation potential of an indigenous microalga Scenedesmus obliquus (Turpin) Kützing GA 45 for biodiesel production. RSC Adv. 2016, 6, 29889-29898. [CrossRef]

83. Hui, W.; Wenjun, Z.; Wentao, C.; Lili, G.; Tianzhong, L. Strategy study on enhancing lipid productivity of filamentous oleaginous microalgae Tribonema. Bioresour. Technol. 2016, 218, 161-166. [CrossRef]

84. Kao, C.-Y.; Chen, T.-Y.; Chang, Y.-B.; Chiu, T.-W.; Lin, H.-Y.; Chen, C.-D.; Chang, J.S.; Lin, C.S. Utilization of carbon dioxide in industrial flue gases for the cultivation of microalga Chlorella sp. Bioresour. Technol. 2014, 166, 485-493. [CrossRef]

85. Ying, K.; Zimmerman, W.; Gilmour, D. Effects of $\mathrm{CO} 2$ and $\mathrm{pH}$ on growth of the microalga Dunaliella salina. J. Microbial. Biochem. Technol. 2014, 6, 167-173. [CrossRef]

86. Peng, L.; Lan, C.Q.; Zhang, Z.; Sarch, C.; Laporte, M. Control of protozoa contamination and lipid accumulation in Neochloris oleoabundans culture: Effects of $\mathrm{pH}$ and dissolved inorganic carbon. Bioresour. Technol. 2015, 197, 143-151. [CrossRef]

87. Ferreira, A.; Marques, P.; Ribeiro, B.; Assemany, P.; de Mendonça, H.V.; Barata, A.; Oliveira, A.C.; Reis, A.; Pinheiro, H.; Gouveia, L. Combining biotechnology with circular bioeconomy: From poultry, swine, cattle, brewery, dairy and urban wastewaters to biohydrogen. Environ. Res. 2018, 164, 32-38. [CrossRef]

88. Tran, D.T.; Yeh, K.L.; Chang, J.S. Enzymatic transesterification of microalgal oil from Chlorella vulgaris ESP-31 for biodiesel synthesis using immobilized Burkholderia lipase. Biotechnol. Bioresour. 2012, 108, 119-127. [CrossRef] [PubMed]

89. Martin, G.J.; Hill, D.R.; Olmstead, I.L.; Bergamin, A.; Shears, M.J.; Dias, D.A.; Kentish, S.E.; Scales, P.J.; Botte, C.Y.; Callahan, D.L. Lipid profile remodeling in response to nitrogen deprivation in the microalgae Chlorella sp. (Trebouxiophyceae) and Nannochloropsis sp. (Eustigmatophyceae). PLoS ONE 2014, 9, e103389. [CrossRef] 
90. Rodolfi, L.; Chini Zittelli, G.; Bassi, N.; Padovani, G.; Biondi, N.; Bonini, G.; Tredici, M.R. Microalgae for oil: Strain selection, induction of lipid synthesis and outdoor mass cultivation in a low-cost photobioreactor. Biotechnol. Bioeng. 2009, 102, 100-112. [CrossRef] [PubMed]

91. Hsieh, C.-H.; Wu, W.-T. Cultivation of microalgae for oil production with a cultivation strategy of urea limitation. Bioresour. Technol. 2009, 100, 3921-3926. [CrossRef] [PubMed]

92. Praveenkumar, R.; Shameera, K.; Mahalakshmi, G.; Akbarsha, M.A.; Thajuddin, N. Influence of nutrient deprivations on lipid accumulation in a dominant indigenous microalga Chlorella sp., BUM11008: Evaluation for biodiesel production. BiomassBioenergy 2012, 37, 60-66. [CrossRef]

93. Li, Y.; Han, F.; Xu, H.; Mu, J.; Chen, D.; Feng, B.; Zeng, H. Potential lipid accumulation and growth characteristic of the green alga Chlorella with combination cultivation mode of nitrogen $(\mathrm{N})$ and phosphorus (P). Bioresour. Technol. 2014, 174, 24-32. [CrossRef]

94. Scragg, A.; Illman, A.; Carden, A.; Shales, S. Growth of microalgae with increased calorific values in a tubular bioreactor. BiomassBioenergy 2002, 23, 67-73. [CrossRef]

95. Adams, C.; Godfrey, V.; Wahlen, B.; Seefeldt, L.; Bugbee, B. Understanding precision nitrogen stress to optimize the growth and lipid content tradeoff in oleaginous green microalgae. Bioresour. Technol. 2013, 131, 188-194. [CrossRef]

96. Lin, Q.; Lin, J. Effects of nitrogen source and concentration on biomass and oil production of a Scenedesmus rubescens like microalga. Bioresour. Technol. 2011, 102, 1615-1621. [CrossRef]

97. Tao, L.; Linglin, W.; Aifen, L.; Chengwu, Z. Responses in growth, lipid accumulation, and fatty acid composition of four oleaginous microalgae to different nitrogen sources and concentrations. Chin. J. Oceanol. Limnol. 2013, 31, $1306-1314$.

98. Yang, L.; Chen, J.; Qin, S.; Zeng, M.; Jiang, Y.; Hu, L.; Xiao, P.; Hao, W.; Hu, Z.; Lei, A.; et al. Growth and lipid accumulation by different nutrients in the microalga Chlamydomonas reinhardtii. Biotechnol. Biofuels 2018, 11, 40. [CrossRef]

99. Kamalanathan, M.; Pierangelini, M.; Shearman, L.A.; Gleadow, R.; Beardall, J. Impacts of nitrogen and phosphorus starvation on the physiology of Chlamydomonas reinhardtii. Environ. Boil. Fishes 2016, 28, 1509-1520. [CrossRef]

100. Cordeiro, R.S.; Vaz, I.C.D.; Sergia, M.S.M.; Barbosa, F.A.R. Effects of nutritional conditions on lipid production by cyanobacteria. An. Acad. Bras. Ciências 2017, 89, 2021-2031. [CrossRef]

101. Mata, T.M.; Almeidab, R.; Caetanoa, N.S. Effect of the culture nutrients on the biomass and lipid productivities of microalgae Dunaliella tertiolecta. Chem. Eng. Transac. 2013, 32, 978-988.

102. Liu, Z.-Y.; Wang, G.-C.; Zhou, B.-C. Effect of iron on growth and lipid accumulation in Chlorella vulgaris. Bioresour. Technol. 2008, 99, 4717-4722. [CrossRef]

103. El Baky, H.A.; El-Baroty, G.S.; Bouaid, A.; Martinez, M.; Aracil, J. Enhancement of lipid accumulation in Scenedesmus obliquus by Optimizing CO2 and Fe3+ levels for biodiesel production. Bioresour. Technol. 2012, 119, 429-432. [CrossRef] [PubMed]

104. Ren, H.-Y.; Liu, B.-F.; Kong, F.; Zhao, L.; Xie, G.-J.; Ren, N.-Q. Enhanced lipid accumulation of green microalga Scenedesmus sp. by metal ions and EDTA addition. Bioresour. Technol. 2014, 169, 763-767. [CrossRef] [PubMed]

105. Gorain, P.C.; Bagchi, S.K.; Mallick, N. Effects of calcium, magnesium and sodium chloride in enhancing lipid accumulation in two green microalgae. Environ. Technol. 2013, 34, 1887-1894. [CrossRef] [PubMed]

106. Battah, M.; El-Ayoty, Y.; Abomohra, A.E.-F.; El-Ghany, S.A.; Esmael, A. Effect of Mn2+, Co2+ and H2O2 on biomass and lipids of the green microalga Chlorella vulgaris as a potential candidate for biodiesel production. Ann. Microbiol. 2014, 65, 155-162. [CrossRef]

107. Arguelles, E.D.L.R.; Laurena, A.C.; Monsalud, R.G.; Martinez-Goss, M.R. Fatty acid profile and fuel-derived physico- chemical properties of biodiesel obtained from an indigenous green microalga, Desmodesmus sp. (I-AU1), as potential source of renewable lipid and highquality biodiesel. J. Appl. Phycol. 2018, 30, 411-419. [CrossRef]

108. Khozin-Goldberg, I.; Cohen, Z. The effect of phosphate starvation on the lipid and fatty acid composition of the fresh water eustigmatophyte Monodus subterraneus. Phytochemistry 2006, 67, 696-701. [CrossRef] [PubMed]

109. Corteggiani, C.E.C.; Telatin, A.; Vitulo, N.; Forcato, C.; D’Angelo, M.; Schiavon, R.; Vezzi, A.; Giacometti, G.M.; Morosinotto, T.; Valle, G. Chromosome scale genome assembly and transcriptome profiling of Nannochloropsis gaditana in nitrogen depletion. Mol. Plant 2014, 7, 323-335. [CrossRef]

110. Juneja, A.; Ceballos, R.M.; Murthy, G.S. Effects of Environmental Factors and Nutrient Availability on the Biochemical Composition of Algae for Biofuels Production: A Review. Energies 2013, 6, 4607-4638. [CrossRef]

111. Cao, J.; Yuan, H.; Li, B.; Yang, J. Significance evaluation of the effects of environmental factors on the lipid accumulation of Chlorella minutissima UTEX 2341 under low-nutrition heterotrophic condition. Bioresour. Technol. 2014, 152, 177-184. [CrossRef]

112. Kan, G.; Shi, C.; Wang, X.; Xie, Q.; Wang, M.; Wang, X.; Miao, J. Acclimatory responses to high-salt stress in Chlamydomonas (Chlorophyta, Chlorophyceae) from Antarctica. Acta Oceanol. Sin. 2012, 31, 116-124. [CrossRef]

113. Rao, A.R.; Dayananda, C.; Sarada, R.; Shamala, T.; Ravishankar, G. Effect of salinity on growth of green alga Botryococcus braunii and its constituents. Bioresour. Technol. 2007, 98, 560-564. [CrossRef] [PubMed]

114. Sharma, K.K.; Schuhmann, H.; Schenk, P.M. High Lipid Induction in Microalgae for Biodiesel Production. Energies 2012, 5, 1532-1553. [CrossRef]

115. Bartley, M.; Boeing, W.J.; Corcoran, A.A.; Holguin, F.O.; Schaub, T. Effects of salinity on growth and lipid accumulation of biofuel microalga Nannochloropsis salina and invading organisms. Biomass- Bioenergy 2013, 54, 83-88. [CrossRef] 
116. Figler, A.; Márton, K.; B-Béres, V.; Bácsi, I. Effects of Nutrient Content and Nitrogen to Phosphorous Ratio on the Growth, Nutrient Removal and Desalination Properties of the Green Alga Coelastrum morus on a Laboratory Scale. Energies 2021, 14, 2112. [CrossRef]

117. Pandit, P.R.; Fulekar, M.H.; Karuna, M.S.L. Effect of salinity stress on growth, lipid productivity, fatty acid composition, and biodiesel properties in Acutodesmus obliquus and Chlorella vulgaris. Environ. Sci. Pollut. Res. 2017, 24, 13437-13451. [CrossRef]

118. Chokshi, K.; Pancha, I.; Ghosh, A.; Mishra, S. Salinity induced oxidative stress alters the physiological responses and improves the biofuel potential of green microalgae Acutodesmus dimorphus. Bioresour. Technol. 2017, 244, 1376-1383. [CrossRef]

119. Srivastava, G.; Nishchal; Goud, V.V. Salinity induced lipid production in microalgae and cluster analysis (ICCB 16-BR_047). Bioresour. Technol. 2017, 242, 244-252. [CrossRef]

120. Sydney, E.; da Silva, T.; Tokarski, A.; Novak, A.; de Carvalho, J.; Woiciecohwski, A.; Larroche, C.; Soccol, C. Screening of microalgae with potential for biodiesel production and nutrient removal from treated domestic sewage. Appl. Energy 2011, 88, 3291-3294. [CrossRef]

121. Jayakumar, S.; Yusoff, M.; Rahim, M.H.A.; Maniam, G.P.; Govindan, N. The prospect of microalgal biodiesel using agro-industrial and industrial wastes in Malaysia. Renew. Sustain. Energy Rev. 2017, 72, 33-47. [CrossRef]

122. Cheng, D.; Ngo, H.; Guo, W.; Chang, S.; Nguyen, D.D.; Kumar, S. Microalgae biomass from swine wastewater and its conversion to bioenergy. Bioresour. Technol. 2019, 275, 109-122. [CrossRef]

123. Diniz, G.S.; Silva, A.F.; Araujo, O.; Chaloub, R.M. The potential of microalgal biomass production for biotechnological purposes using wastewater resources. J. Appl. Phycol. 2017, 29, 821-832. [CrossRef]

124. Fields, M.W.; Hise, A.; Lohman, E.J.; Bell, T.; Gardner, R.D.; Corredor, L.; Moll, K.; Peyton, B.M.; Characklis, G.W.; Gerlach, R. Sources and resources: Importance of nutrients, resource allocation, and ecology in microalgal cultivation for lipid accumulation. Appl. Microbiol. Biotechnol. 2014, 98, 4805-4816. [CrossRef] [PubMed]

125. Zhou, W.; Li, Y.; Min, M.; Hu, B.; Chen, P.; Ruan, R. Local bioprospecting for high-lipid producing microalgal strains to be grown on concentrated municipal wastewater for biofuel production. Bioresour. Technol. 2011, 102, 6909-6919. [CrossRef]

126. Li, Y.; Zhou, W.; Hu, B.; Min, M.; Chen, P.; Ruan, R.R. Effect of light intensity on algal biomass accumulation and biodiesel production for mixotrophic strains Chlorella kessleri and Chlorella protothecoide cultivated in highly concentrated municipal wastewater. Biotechnol. Bioeng. 2012, 109, 2222-2229. [CrossRef]

127. Cabanelas, I.T.D.; Arbib, Z.; Chinalia, F.A.; Souza, C.O.; Perales, J.A.; Almeida, P.F.; Druzian, J.I.; Nascimento, I.A. From waste to energy: Microalgae production in wastewater and glycerol. Appl. Energy 2013, 109, 283-290. [CrossRef]

128. Singh, A.; Ummalyma, S.B.; Sahoo, D. Bioremediation and biomass production of microalgae cultivation in river water contaminated with pharmaceutical effluent. Bioresour. Technol. 2020, 307, 123233. [CrossRef]

129. Collos, Y.; Harrison, P. Acclimation and toxicity of high ammonium concentrations to unicellular algae. Mar. Pollut. Bull. 2014, 80, 8-23. [CrossRef]

130. Samorì, G.; Samorì, C.; Guerrini, F.; Pistocchi, R. Growth and nitrogen removal capacity of Desmodesmus communis and of a natural microalgae consortium in a batch culture system in view of urban wastewater treatment: Part I. Water Res. 2013, 47, 791-801. [CrossRef]

131. Salama, E.-S.; Kurade, M.; Abou-Shanab, R.A.; El-Dalatony, M.M.; Yang, I.-S.; Min, B.; Jeon, B.-H. Recent progress in microalgal biomass production coupled with wastewater treatment for biofuel generation. Renew. Sustain. Energy Rev. 2017, 79, 1189-1211. [CrossRef]

132. Dębowski, M.; Zieliński, M.; Kazimierowicz, J.; Kujawska, N.; Talbierz, S. Microalgae Cultivation Technologies as an Opportunity for Bioenergetic System Development-Advantages and Limitations. Sustainability 2020, 12, 9980. [CrossRef]

133. Bošnjaković, M.; Sinaga, N. The Perspective of Large-Scale Production of Algae Biodiesel. Appl. Sci. 2020, 10, 8181. [CrossRef]

134. Mehariya, S.; Goswami, R.; Verma, P.; Lavecchia, R.; Zuorro, A. Integrated Approach for Wastewater Treatment and Biofuel Production in Microalgae Biorefineries. Energies 2021, 14, 2282. [CrossRef]

135. Silkina, A.; Ginnever, N.E.; Fernandes, F.; Fuentes-Grünewald, C. Large-Scale Waste Bio-Remediation Using Microalgae Cultivation as a Platform. Energies 2019, 12, 2772. [CrossRef]

136. Park, S.; Ahn, Y.; Pandi, K.; Ji, M.-K.; Yun, H.-S.; Choi, J.-Y. Microalgae Cultivation in Pilot Scale for Biomass Production Using Exhaust Gas from Thermal Power Plants. Energies 2019, 12, 3497. [CrossRef]

137. Sasongko, N.A.; Noguchi, R.; Ito, J.; Demura, M.; Ichikawa, S.; Nakajima, M.; Watanabe, M.M. Engineering Study of a Pilot Scale Process Plant for Microalgae-Oil Production Utilizing Municipal Wastewater and Flue Gases: Fukushima Pilot Plant. Energies 2018, 11, 1693. [CrossRef] 